\title{
Do laws influence the cost of real estate brokerage services? A state fixed effects approach
}

Article

Accepted Version

Nanda, A., Clapp, J. M. and Pancak, K. A. (2016) Do laws influence the cost of real estate brokerage services? A state fixed effects approach. Real Estate Economics, 44 (4). pp. 918-967. ISSN 1540-6229 doi: https://doi.org/10.1111/15406229.12124 Available at https://centaur.reading.ac.uk/43159/

It is advisable to refer to the publisher's version if you intend to cite from the work. See Guidance on citing.

To link to this article DOI: http://dx.doi.org/10.1111/1540-6229.12124

Publisher: Wiley

All outputs in CentAUR are protected by Intellectual Property Rights law, including copyright law. Copyright and IPR is retained by the creators or other copyright holders. Terms and conditions for use of this material are defined in the End User Agreement.

www.reading.ac.uk/centaur 
Central Archive at the University of Reading

Reading's research outputs online 


\section{Do Laws Influence the Cost of Real Estate Brokerage Services? A State Fixed Effects Approach}

Anupam Nanda*, John M. Clapp**, Katherine A. Pancak***

The FTC-DOJ (2007) study argues that state laws and regulations may inhibit the unbundling of real estate brokerage services in response to new technology. Our data show that eighteen states have changed laws in ways that promote unbundling since 2000. We model brokerage costs as measured by number of agents in a state-level annual panel vector auto-regressive ( $V A R$ ) framework, a novel way of analyzing wasteful competition. Our findings support a positive relationship between brokerage costs and lagged house price and transactions. We find that change in full service brokers responds negatively (by well over 2 percentage points per year) to legal changes facilitating unbundling.

A significant stream of research has focused on inefficient overproduction of real estate brokerage services (Yinger, 1981; Miceli, 1992; Yavas, 1992; Turnbull, 1996). New empirical findings support this idea. Hsieh and Moretti (2003) find that the productivity of real estate brokers as measured by houses sold per hour worked declines when the price of land increases in a city; they attribute this to overproduction of services (i.e., unnecessary increase in costs of selling a house) generated by relatively fixed commissions and entry of new brokers. ${ }^{1}$ In a more recent study of MSA-level variation, Han and Hong (2012, HH hereafter) find that a 10\% increase in number of brokers will increase costs by $12.4 \%$, and that more than one third of this effect can be attributed to wasteful non-price competition.

* Henley Business School, University of Reading, UK or a.nanda@reading.ac.uk

** Center for Real Estate and Urban Economic Studies, School of Business, University of Connecticut, Storrs, CT 06269 or john.clapp@uconn.edu

*** Center for Real Estate and Urban Economic Studies, School of Business, University of Connecticut, Stamford, CT 06901 or katherine.pancak@uconn.edu

\footnotetext{
${ }^{1}$ We use the term "brokers" to refer to licensed brokers and sales agents.
} 
The primary purpose of this study is to ask whether the framework of laws and regulations governing real estate brokerage can significantly reduce costs by establishing an environment conducive to more efficient unbundling of brokerage services. If so, then the number of full service brokers should respond to house prices, transactions and law change as predicted by models of the inefficient over-production of brokerage services. Our research is motivated by regulatory changes on Wall Street in the 1970's that allowed discount brokers to pass the benefits of new technology to customers. The result was a large increase in trading on stock markets.

The literature points to two characteristics of the industry - low barriers to entry and inflexible commission rates - as the main factors driving inefficiency. ${ }^{2}$ The hypothesis of low entry barriers is generally accepted by industry observers, but the assertion of inflexible commission rates has been contested by the National Association of Realtors (NAR). However, Beck, Scott, and Yelowitz (2012) point to the natural monopoly aspect of the Multiple Listing Service (MLS), where brokers on both sides of the transaction share information and cooperate to complete a deal. Other studies point to MLS as the major reason that commission rates are high, attracting entry of more brokers than required to efficiently facilitate transactions (Yavas and Colwell, 1999; Woodall and Brobeck, 2006). Even if the MLS is not the cause, evidence of relatively fixed commissions continues to garner support: see Barwick and Pathak (2015), Jia and Pathak (2010) and Wiley, Zumpano, and Benefield (2011).

Improvements in technology - notably online listings with substantial visual and written information on properties and neighborhoods - should reduce the real economic costs of selling property by reducing the need for human time. Some brokers have used technology to unbundle the traditional

\footnotetext{
2 If entry is a function of reservation wage, as in Benjamin, Chinloy, and Winkler (2009), then a real increase in land
} value will cause entry, driving wages back to the reservation wage. 
full package of brokerage services and offer real estate consumers the option of purchasing a limited level of services at reduced fees. ${ }^{3}$ Hendel, Nevo and Ortalo-Magne (2009) found that sellers are unlikely to receive a significantly lower sales price if they use a limited service broker. Levitt and Syverson (2008) and Wiley, Zumpano, and Benefield (2011) concluded that residential real estate consumers using limited-service flat-fee brokers are not worse off than those using traditional fullservice, full-commission brokers. ${ }^{4}$ Rutherford and Yavas (2012) look at similar issues when using discount brokers in residential transactions. They find that houses listed by discount brokers sell at prices similar to non-discount brokerage listings, but with lower probability of sale and longer time on the market.

This paper develops econometric models capable of evaluating the effect of public policy on the real economic costs of brokerage services in human time as measured by number of full service brokers (a term that we use to include sales agents as well) per unit service. ${ }^{5}$ Hsieh and Moretti (2003) measure productivity as properties sold per broker and $\mathrm{HH}$ measure cost as a function of total brokers per sale and number of sales. In a time series context, the stationary counterpart is change in number of brokers per unit service; services are measured by number of transactions or population

\footnotetext{
${ }^{3}$ For example, Select A Fee Real Estate System ${ }^{\mathrm{TM}}$ lets a home seller choose a desired level of services for a fixed fee, not the traditional package of services for a percentage of the sales price. With their "Bare Bones Service" a seller can hire a listing broker to sell his or her house for only $\$ 350$ plus $2.5 \%$ commission. For this price, the listing agent will place the property on a multiple listing service, and eventually help negotiate the contract, but the seller must show the home and hold open houses. Flat Fee Listing advertises that it will enter into an arrangement with a seller to provide only entry to the local multiple listing services for $\$ 249$, as a way to assist For Sale By Owner (FSBO). For these and other examples of offering unbundled limited services, see www.selectafee.com, www.flatfeelisting.com, www.listbyownerinmls.com, www.mlsmart.com, www.aflatfee.com, and www.valuemls.com (last accessed November, 2014).

${ }^{4}$ But for different reasons, Levitt and Syverson (2008) found that houses listed with limited service brokers take longer to sell but eventually sell at similar prices to those listed with full-service brokers. The authors weighed the trade-off between the lower fees charged by a limited-service broker and the longer time on the market, and reasoned that consumers were not worse off than those using full-service brokers. Wiley et al. (2011) found that limited service brokers do not increase a property's time on the market, and that selling price is not significantly different than with full service brokers.

${ }^{5}$ Technology substitutes capital for labor, but it won't be adopted unless this substitution is profit maximizing. Since labor is a large percent of the cost of brokerage services (Han and Hong, 2012; Benjamin et al., 2009), we should see a reduction in brokers per unit service when technology is adopted in the absence of barriers to efficiency.
} 
(a measure of potential demand from all who might transact) or income. ${ }^{6}$ With change in brokers (or brokers per unit service) as a dependent variable, our model predicts that change in lagged house prices and transactions will be positively associated with number of brokers because of free entry or exit and fixed commissions. I.e., when house prices go up (down) then brokerage becomes more (less) profitable relative to other occupations, driving the number of brokers to change positively (negatively).

We use NAR brokers are a proxy for the cost of full services because brokers are typically $60-70 \%$ of operating costs and because NAR policies cater to full service firms as indicated by a 2008 settlement of a suit brought by the DOJ. This proxy ignores variation across brokers in expertise and experience so our results must be interpreted as average effects across all states for a typical broker. Since we do not observe hours worked, our results are conservative: i.e., a legal change will likely effect hours worked in the same direction as it influences number of full service brokers as suggested by Benjamin, Chinloy and Winkler (2009). ${ }^{7}$

Many changes to the institutional, regulatory and legal framework occur at the state level (hereafter, “state laws"). We propose a panel VAR model of brokerage costs using state-level data because it builds on the structural framework proposed by $\mathrm{HH}$ while allowing for considerable unobserved heterogeneity across US states. The VAR framework provides a robust method for determining the effect of statewide legal changes on brokerage costs while allowing endogeneity of all variables in the VAR system.

\footnotetext{
${ }^{6}$ Typically, $60-70 \%$ of gross revenue to real estate brokerage is paid to agents for their services, so number of agents is a good proxy for costs. One source states that agents start "at 70 percent [of gross revenue] and bumps them up to 75 percent when they gross $\$ 150,000 ; 80$ percent for $\$ 250,000$ and 90 percent for $\$ 500,000$. “

http://therealdeal.com/issues articles/splits-grow-more-crucial-as-market-tightens/, last accessed in June, 2015.

${ }^{7}$ Further discussion of DOJ's suit is contained in Section 3.1 and the omitted variables argument for hours worked is in Section 4.1.
} 
In order to apply a state fixed effects model, we need to aggregate from local markets to the state level. Aggregation is a reasonable approximation for a study of brokerage costs for several reasons; most importantly, the economic cost of brokerage services exhibit little overall economies of scale (Anderson, Lewis, and Zumpano, 2000). ${ }^{8}$ Secondly, we study laws and regulations that apply equally throughout the state, so aggregation allows determination of the average statewide effect: constant costs as a function of firm size justifies our interpretation of regression parameters as average effects of legal changes on cost. Thirdly, we test our models for aggregation biases with limited MSA-level data. With derived information on number of brokers and transactions at the MSA level, we find that our main results are robust to MSA-level heterogeneity.

We investigate changes in the legal (and regulatory) framework governing waivable minimum services and commission rebates. Moreover, non-agency (also known as transactions brokers or facilitators), like provisions allowing minimum services to be waived, reduce legal risk by removing liability for fiduciary duties. These three legal changes are chosen because they constitute the most important legal barriers to reaping benefits from adoption of technology: see a comprehensive report on these issues by the FTC-DOJ (2007). ${ }^{9}$

New aspects of our study include:

1. Where previous researchers used cross-sectional data, or changes between decennial census dates, we use annual time series on changes in full service brokers at the state level.

\footnotetext{
${ }^{8}$ Zumpano, Elder and Crellin (1993) use translog production functions to model the cost structure. They show that very small firms operate inefficiently, but that average total costs are relatively constant for a broad range of firm sizes typical in the industry. Diseconomies of scale characterize the largest firms, but there is relatively little market concentration outside of the smallest cities (Beck et al., 2012).

${ }_{9}^{9}$ Our comprehensive review of legal changes during the period 2000-2012 (see Appendix tables A1 - A3) shows that nine states with minimum services laws made changes allowing them to be waived by agreement among the parties. Sixteen states had anti-rebate laws; seven rescinded. Three states changed to allow non-agency relationships during our sample period. Thus, our data show a trend towards legal changes that support unbundling of brokerage services.
} 
2. Our reduced form VAR model provides a novel way of analyzing wasteful competition; it allows for dynamic co-dependence between numbers of full service brokers and house prices and other variables while placing minimal restrictions on the data. ${ }^{10}$

3. By aggregating to the state level, we include non-metropolitan activity, a significant share at about 25 percent of the housing stock.

4. As a robustness check we develop a method for imputing number of brokers and transactions at the MSA level, a method transferable to other statewide regulatory changes. For example, states have enacted consumer protection laws that address broker licensing, duties, and practices. ${ }^{11}$

5. We control for time-invariant heterogeneity by differencing the data at the state level.

6. We add dummies for changes in state law and regulation to the differenced VAR system, introducing a differences-in-differences (DID) procedure to control endogeneity and omitted variable bias.

7. We further control for endogeneity of changes in state policy with two stage least squares and with dynamic panel methods (Arellano and Bond, 1991; Arellano and Bover, 1995).

Panel VAR results confirm the findings of Hsieh and Moretti (2003) that change in full service brokers is positively related to change in house prices after controlling for the level of service, implying wasteful competition. The elasticity of brokers per unit service to house prices is positive in all models, with parameters greater than 0.12 in our preferred specifications. The predictions of the

\footnotetext{
${ }^{10}$ While we cannot recover structural parameters from the panel VAR model, we can take another difference based on changes in state legal frameworks, and our interest centers on the effect of these changes.

11 Changing provisions relating to real estate brokerage practices include duties to parties (escrowing of monies, submitting all offers, cooperating with other brokers), documents required to be given to consumers (agency disclosures, property condition disclosures), that a broker can represent a buyer (limiting the historical concept of sub-agency), whether a broker can represent both buyers and sellers in the same transaction (dual agency, designated agency), and whether a broker has to represent a consumer at all (non-agency transaction brokerage).
} 
model are robust when the unit of service is specified as change in brokers per capita or as change in brokers per dollar income.

Our approach complements HH, who use 2000 PUMS data for 160 free-standing MSAs. Once we recast their cost function in a panel VAR context, then changes in laws and regulations can be introduced as a second difference: the effect of the legal change is captured by the effect of a law dummy on the dependent variable, which is already a first difference at the state level. We show that change in full service brokers responds negatively when anti-rebate laws are rescinded, as predicted by $\mathrm{HH}$. This result is robust to several alternative specifications, to various controls for endogeneity and to annual time dummies. ${ }^{12}$

We find that the enactment of waivable minimum service and non-agency provisions reduced growth in full service brokers. I.e., our evidence suggests that laws allowing transactions facilitators or limited service brokers tended to clarify brokerage duties, reducing legal risk and encouraging unbundling of brokerage services. However, results are not robust to yearly time dummies; this is likely because of the clustering of regulatory changes in the middle of the 2000's. Combining all three legal changes reduces annual growth in full service brokers by more than two percentage points a year, a result that is robust to yearly time dummies and alternative model specifications.

Rest of the paper is presented as follows: in the next section, we provide a theoretical framework for statewide aggregation of firm-level costs. Section 3 provides detail on state laws and regulations influencing brokerage costs, with a focus on laws identified by the FTC-DOJ (2007) study. The

\footnotetext{
12 Some models adjust for pre-trends as suggested by Wolfers (2006). Results are robust to this adjustment.
} 
empirical framework is presented in Section 4, which is followed by data and summary statistics. In section 6, we discuss the results. Some concluding remarks are made in section 7 .

\section{A Model of Economic Costs at the Firm and State Level}

State level aggregation of local service industries has been found useful in many areas. Bates and Santerre (2013) aggregated costs from individual hospital and nursing facilities to the state level in order to use fixed effects to determine the effect of statewide economic indicators on costs. Johnson and Raphael (2009) aggregate individual AIDs cases that are transmitted locally to the state level. This allows them to use nested fixed effects models, and lagged variables, to evaluate the effects of incarceration on AIDS transmission by race, age, gender and year. Similarly, we propose to use lagged variables as part of our identification strategy. We conclude that aggregation is an issue primarily because of a long tradition of MSA level analysis of the brokerage industry. We begin our analysis with a firm-level model.

\section{Firm-level Analysis}

We study real economic costs of a typical transaction, not commission rates paid by buyers and sellers. For this reason, our model is based on the theoretical framework in HH. Let bkr $S_{j t}$ be the number of full service brokers per unit service (transactions or, we will argue, population) in firm $j$ at time $t^{13}$ Brokers get paid a reservation wage specific to each firm, $w_{j t}$, as in Benjamin et al. (2009). We model total cost as a multiple, $m_{t}$, times variable costs: i.e., we assume all costs are variable or equivalently that firms operate at approximately the same average total cost regardless of scale (see

\footnotetext{
13 Our theory is developed for full service brokers. This distinguishes the type of agent referenced by $\mathrm{HH}$ from a transactions agent or fee-for-service provider. Theory is based on full service brokers charging a fixed commission. We expect that legal and regulatory changes promoting the unbundling brokerage services will reduce the number of full service brokers.
} 
Zumpano et al., 1993 and Anderson et al., 2000). This assumption is not restrictive because we will specify our model in change form.

The total cost $\left(C_{j t}\right)$ of $S_{j t}$ units of service in firm $j$ at time $t$ is:

$$
C_{j t}=S_{j t} w_{j t} h_{t} b k r S_{j t} m_{t}
$$

where $h_{t}$ is the hours worked per broker which changes over time as employees change their allocation between part-time and full-time work. Benjamin et al. (2009) present evidence that the supply elasticity of hours is about 0.21 for full-time workers (i.e., over 20 hours per week) and near zero for part-time workers. Since we lack data on $h_{t}$, we will assume that it is constant. Section 4 shows that this positive supply elasticity implies that our estimates of response to house prices are conservative.

We model economic costs per unit $\operatorname{service} c_{j t}$ as a linear function of full service brokers per unit service:

$c_{j t}=\frac{C_{j t}}{w_{j t} m_{t} S_{j t}}=f\left(b k r S_{j t}\right)+\delta_{j t}+\varepsilon_{j t}$

Unobserved heterogeneity is captured by $\varepsilon_{j t}$, and fixed effects for $\delta_{j t}$ allows for labor market differences such as differences in opportunity costs of employment or in concentration of labor by 
skill level. The function $f()$ indicates that we will allow for endogeneity between number of brokers and service levels; it is a linear approximation.

To aggregate, costs per unit service are averaged at the state level; there are $N_{i}$ firms in state $i:^{14}$

$$
\sum_{j=0}^{N_{i}} c_{j t} / N_{i}=c_{i t}=f\left(b k r S_{i t}\right)+\delta_{i t}+\varepsilon_{i t}
$$

To keep the notation simple, equation (2.3) indicates averaging only by using the subscript $i$ on the right hand side, $i=1, \ldots, 51$ states. For example, change in notation from $c_{j t}$ in equation (2.2) to $c_{i t}$ in equation (2.3) indicates that the cost variable has been averaged over all firms in the state. An important strength of equation (2.3) is that we can include firms in rural areas as part of the aggregation, whereas most empirical studies focus on firms within MSAs, or MSA level aggregation. The plausibility of modeling heterogeneity over time and space in wages and fixed costs with $\delta_{i t}+\varepsilon_{i t}$ will be presented as part of our panel VAR model of changes in full service brokers.

The statistical effects of aggregation are to cause some loss of efficiency in the estimation of equation (2.3), since there is presumably correlation across the $N_{i}$ firms. However, this is offset by reduction in measurement error since random errors in each variable will tend to cancel out at the state level. ${ }^{15}$ The main empirical implication of equation (2.3) is that full service brokers per unit service can proxy for economic costs under the assumptions required for equation (2.1). When estimating (2.3), we must allow for the fact that some heterogeneity comes from including firms in

\footnotetext{
${ }^{14}$ Following the literature summarized above, we assume that costs per unit service are roughly constant across firms. 15 See Cetorelli and Strahan (2006) for a discussion of aggregation.
} 
rural areas, and smaller MSAs, where market structure and therefore costs are likely to differ from large MSAs. In section 4, we will introduce variables and methods for dealing with $\delta_{i t}$ and $\varepsilon_{i t}$.

\section{State Laws and Regulation Influencing Real Estate Brokerage Costs}

Increasing use of web-based search tools and technology has changed the way some real estate consumers use brokerage services. The internet allows buyers to obtain substantial information about listings and transactions in the area where they may purchase, and they can obtain information on neighborhood characteristics. ${ }^{16}$ They can also obtain listing information from FSBO sites, Craiglist and similar services. When a buyer informed by the internet approaches a real estate agent, the amount of time required for the agent to match the buyer with a seller has been reduced. ${ }^{17}$

Likewise, sellers can obtain internet information on transactions in their neighborhood so they can form their own opinion about a listing price and derive future price expectation. More importantly, sellers listing their property on the MLS obtain wide exposure through the internet, reducing the time and resources expended by the agent to match the seller with a buyer. Some sellers may have enough information to use the agent only to list the property on the MLS and/or to facilitate closing of the transaction, rather than requiring a full set of services such as open houses and print advertising. ${ }^{18}$ In response, limited service brokers and transactions facilitators have entered the market in states that allow them.

\footnotetext{
16 As pointed out by the FTC-DOJ (2007) report, listing information obtained from the internet (using the "IDX" database) is not as detailed or as current as information obtained from the MLS through a real estate agent. However, a buyer who uses the internet before approaching an agent is still well informed relative to one who does not use the internet. The FTC-DOJ study reports that a substantial portion of buyers were using the internet in 2006 (FTC-DOJ, p 25).

${ }^{17}$ We use the term "agent" to reference the possibility that transactions brokers or fee-for-service providers substitute for full service brokers.

${ }^{18}$ Hendel et al. (2009) points out that certain segments of buyers and sellers (e.g., those with the time and resources to access the internet) may use technology to reduce the cost of their transactions.
} 
The FTC-DOJ (2007) lists several reasons why agent productivity (sales per agent) might not reflect the real cost savings allowed by the internet. Some of these are institutional: the complexity of the real estate transaction; limited knowledge on the part of many buyers and sellers; restrictions imposed by the MLS; and the unwillingness of some brokers to cooperate with those unbundling services and charging lower fees.

Another set of restrictions are imposed by state laws and regulation. Our focus on minimum services, non-agency and anti-rebate laws is based on the FTC-DOJ study which lists these as leading causes of "substantial consumer harm" (p2). The DOJ has lobbied state legislatures not to enact minimum service laws and has threatened litigation in states with anti-rebate laws.

We hand-collected data on changes in minimum service, non-agency and anti-rebate laws and regulations during the period from 2000 through 2012, when these laws changed in many states. These law changes allow unbundling of brokerage services and therefore imply reduction in costs. Figure 1 summarizes the legal interventions. Appendix tables provide details for each state.

[Insert Figure 1 here]

\section{Waivable Minimum Services and Non-agency Changes}

Minimum service laws require brokers to perform specific duties for buyers and sellers. We define minimum services as statutory or regulatory requirements that a broker or transactions agent perform certain minimum brokerage undertakings for a real estate consumer. These services typically include assisting the consumer by accepting delivery of and presenting offers, assisting in negotiating, and answering questions. Some states only require that agents perform these services if they represent the client in an agency relationship; some states only require them in an exclusive 
agency relationship. Waivable minimum services are the same types of legal requirements, but with a provision in the law that the requirements are waivable by agreement and therefore not binding: see Appendix table A1. This is significant difference because the waivable laws appear to clarify common law brokerage expectations but allow a lower level to be provided. For example, Delaware's 2006 change requires that agents be reasonably available to a client to accept offers, assist in negotiation and answer questions. However, the law allows the client to waive these duties. In effect, this abrogates the common law of agency, allowing unbundling of services.

Nine states allow minimum service laws to be waived, reducing liability for failure to perform fiduciary duties; appendix table A1 contains details. All these provisions were enacted in the period from 2006 to 2008, allowing application of our DID methods. These changes provide a quasinatural experiment since they clearly enact reduction in legal liability related to unbundling of services.

Figure 2 shows the average number of brokers - measured by NAR members - in the nine waivable states compared to states with no waivable provision and those with no change in law of any kind. ${ }^{19}$ For the majority of the time frame of this study, the NAR explicitly advocated full service, traditional brokerage. As evidence, the Antitrust Division of the DOJ sued NAR in 2005, alleging that NAR policies and rules prevented their members from working with other brokers offering limited services and MLS-only listings. The suit was settled in 2008, with new NAR policies going into effect in 2009. ${ }^{20}$ NAR's full service emphasis is still evident in 2014: NAR members must commit to a code of conduct with more than 30 different articles, including 10 specific ways they are

\footnotetext{
19 The no law change line excludes states that changed anti-rebate provisions.

20 See http://www.justice.gov/archive/opa/pr/2008/May/08-at-467.html (last accessed in October 2014).
} 
to cooperate with other Realtors ${ }^{\mathrm{TM}^{21}}$. It is unlikely that transactions brokers or facilitators will pay the additional fees required of NAR members. ${ }^{22}$

Figure 2 suggests that waivable minimum services reduced the demand for full service brokers, as measured by NAR members. Our econometric models will determine the significance of this difference and control for endogeneity and other factors.

$$
\text { [Insert Figure } 2 \text { here] }
$$

States that allow non-agency relationships are similar to those with waivable minimum services in that fiduciary responsibilities do not necessarily apply. Twenty one states allow some form of nonagency; Appendix table A2 contains details. However, only three of these states changed to nonagency after 2000, too few for application of our DID identification strategy. Both non-agency and waivable minimum services facilitate transactions agents, so we combine them into a single law change dummy variable with nonzero observations for 12 states. $^{23}$

\section{Anti-rebate Laws}

FTC-DOJ study (2007) uses the term rebate to include various inducements to convince buyers and sellers to close a transaction: e.g., gift certificates as well as cash rebates (p15). They point out that rebates are a powerful tool for price competition: "without rebates, if the buyer's broker were simply

\footnotetext{
${ }^{21}$ See http://www.realtor.org/sites/default/files/publications/2014/Policy/2014-Code-of-Ethics-and-ArbitrationManual.pdf

22 A NAR convention, November 2014 in New Orleans emphasizes sessions unlikely to interest a transactions facilitator. The conference includes a number of technology sessions, but they are oriented towards closing the transaction, gaining face-to-face contact with a client and office management. See http://www.realtor.org/educsess.nsf/ProgramsbyDateAll?OpenForm (last accessed October 2014).

${ }^{23}$ We built an average of a 4.5 month lag into all our dummy variables. For example, if a law change was passed in 2005 , typically taking effect in July or in October, our dummy variable was coded one in 2006 and subsequent years.
} 
to reduce his or her commission, the savings would go the seller's broker, not to the home buyer" (p. 15).

The use of rebates to pass cost savings on to buyers and sellers informs our identification of changes in anti-rebate states: details for each state are provided in appendix table A3. For example, New Jersey has long-standing anti-rebate laws but in 2005 it changed its statutes to allow rebates to buyers only. Given the special importance of this type of rebate to real estate brokerage, we count the 2005 change as a rescission. By way of contrast, Alaska, which also has anti-rebate laws pre-dating 2000, enacted legislation in 2012 allowing real estate agents to donate money to charities chosen by buyers or sellers. We did not deem this to facilitate transactions in the same way as rebates directly to the principals, so we did not count this as a revision.

The overall conclusion from our state-level analysis of legal changes is that no states have enacted anti-rebate laws since 2000 and seven states have rescinded them. ${ }^{24}$ This provides a natural experiment for the DID methodology. After rescission, we expect the growth in full service brokers (as measured by NAR membership) to be less than before.

Next, we discuss our empirical methodology. A major focus there is to address the endogeneity issue: we need to control for the fact that costs may drive law adoption rather than the other way around. Similarly, we will address the concern that some missing variable, correlated with costs, explains law adoption and rescission.

\footnotetext{
24 Montana enacted an anti-rebate law in 2007 and rescinded it in 2008. We did not include Montana as having an antirebate law. But we did record it as having a rescission effective in 2009. I.e., the state clarified that rebates are allowed.
} 


\section{Empirical Framework}

Equation (2.3) says that the economic costs of brokerage services can be approximated by state level full service brokers per unit service, $b k r S_{i t}$, provided that observed and unobserved heterogeneity are correctly modeled by the last two terms in the equation. HH, Barwick and Pathak (2015), Hsieh and Moretti (2003) and Beck et al. (2012) provided substantial evidence for this approximation and for easy entry and exit in response to the changing conditions in the housing market and fixed commission rates. Their findings imply that wasteful non-price competition will be evidenced by the following:

- When house prices increase, the number of full service brokers will increase because returns per transaction have increased; likewise, decreases in prices will lead to exit of brokers.

- When transactions change, the number of full service brokers changes in the same direction because returns are directly proportional to transactions per broker.

One can think of other variables that influence entry and exit. The VAR model of differences in full service brokers will deal with these concerns as discussed below.

A key issue here is the length of lags required for brokers to adjust at the state level. Entry and exit may be easy, but it takes some time for brokers to respond to changes in house prices and/or number of transactions. We introduce lags into the empirical model:

$$
b k r S_{i t}=\beta_{0}+\beta_{1} b k r S_{i t-s}+\beta_{2} H P I_{i t-s}+\beta_{3} \operatorname{Trans}_{i t-s}+\delta_{i t}+\varepsilon_{i t}
$$

Here, $t$-s represents a lag structure, HPI is a house price index in state $i$ at time $t$, and Trans is the number of transactions. The last two terms model observed and unobserved heterogeneity as in equation (2.3). 


\section{Differences-in-differences and Dynamic Panel Models of Cost}

In specifying equations (4.1), we have explicitly assumed strict exogeneity between the regressors and the error term. This assumption of orthogonality in OLS is easily violated in a panel data framework due to an overriding presence of unobserved heterogeneity in the last two terms of equation (4.1). This is especially problematic when we are dealing with states (or geographic regions) with multitude of dissimilarities. Any well-specified model would still stand to have missed several attributes that are intrinsically associated with the variables included. The unobserved effects (both cross-sectional and temporal) can be specified in a two-way error component model:

$\delta_{i t}=\mu_{i}+\lambda_{t}$

where $\mu_{i}$ denotes state-specific fixed effects and $\lambda_{t}$ year-specific effects. The year effects remove any influence from the national business cycle.

The standard procedure for removing unobserved heterogeneity is the Fixed Effect or LSDV (Least Squares Dummy Variable) specification which is equivalent to 'de-meaning' or 'mean-differencing' the variables across cross-sections and time-periods respectively. But this still leaves some correlation with the mean component of the error term. Here, we take time series differences at the state level in order to eliminate $\mu_{i}$, and to approximate stationarity in other variables:

$$
\Delta b k r S_{i t}=\gamma_{1}+\beta_{1} \Delta b k r S_{i t-s}+\beta_{2} \Delta H P I_{i t-s}+\beta_{3} \Delta \operatorname{Trans}_{i t-s}+\Delta \lambda_{t}+\Delta \varepsilon_{i t}
$$


Equation (4.3) will be recognized as a type of differences-in-differences model (see Jayaratne and Strahan, 1996). ${ }^{25}$ We expect positive signs on the autoregressive parameters, $\beta_{1}$. Transactions should be positively related because they measure service levels and any changes in NAR penetration.

The $\beta_{2}$ parameters are the coefficients of interest in equation (4.3) since they directly capture the relationship between house prices and costs. The dependent variable should be the change in total hours worked as in equation (2.1) but we do not have state level data over time on hours worked by full service real estate brokers. But, hours vary positively with bker $S_{i t}$ for the reasons given by Hsieh and Moretti (2003) and by Benjamin et al. (2009). The changes in excess returns that motivate entry or exit of brokers will likewise motivate changes in hours in the same direction. By a standard omitted variables argument, the $\beta_{2}$ parameters will be conservative (downwardly biased) estimates of the response of costs to changes in house prices. ${ }^{26}$ For these reasons, we omit hours, but qualify interpretation of $\beta_{2}$ accordingly.

The differences-in-differences approach in equation (4.3) has a number of advantages, providing a useful baseline model. However, some econometric issues such as serial correlation, heteroscedasticity and, most importantly, endogeneity are associated with estimating this model ${ }^{27}$. We use a panel VAR approach to deal with co-dependency of the variables: i.e., we recast equation (4.3) as:

\footnotetext{
${ }^{25}$ DID follows because one difference is state demeaning and the second is differences over time. An additional feature of our model is the lagged dependent variable to control for dynamic feedbacks.

${ }^{26}$ Intuitively, change in total hours will have more variation than change in brokers, so the $\beta_{2}$ parameters would be greater if the dependent were total hours. The omitted variables argument follows by moving hours to the right hand side where it enters as an omitted variable with a negative sign. This sign, together with the positive correlation with change in house prices, implies that the parameter of interest is downwardly biased. A similar argument applies to relative wages since wages and hours are likely to be positively related.

${ }^{27}$ See Baltagi (2008) for an accessible, detailed discussion.
} 
$\Delta Y_{i t}=\Gamma_{0}+\Gamma_{1} \Delta Y_{i t-s}+D_{t}+e_{i t}$

where

$\Delta Y_{i t}=\left\{\Delta b k r S_{i t}, \Delta H P I_{i t}, \Delta\right.$ Trans $\left._{i t}\right\}$ and $D_{t}=$ year fixed effects.

Equations (4.4) and (4.5), the standard form of panel VAR, allow us to calculate robust standard errors. We are agnostic as to expected signs in the $\Delta H P I_{i t}$ and $\Delta T_{r a n s}$ equations because of our focus on the effect of law changes on $\Delta b k r S_{i t}$.

\section{Effect of Law on Cost}

The effects of laws and regulations (hereafter "law") on the panel VAR are introduced with a series of law dummy variables and interaction terms:

$$
\Delta Y_{i t}=\Gamma_{0}+\Gamma_{1} \Delta Y_{i t-s}+\alpha_{t} D_{t}+\alpha_{2} \Delta l a w_{i t}+\Gamma_{2} \Delta l a w_{i t} \Delta Y_{i t-s}+\mu_{i}+e_{i t}
$$

Here, $\Delta l a w_{i t}$ is a vector of dummies equal to 1 if state $i$ changed a specific type of law influencing costs at time $t$, otherwise zero; a 4.5 month lag is included since a law that changed in 2005 would not be fully effective until 2006 when we code the dummy as one. We introduce law as a dummy because law changes are a shock to the reduced form VAR. We allow any law change to shift the VAR system by state, identifying the law effect by comparing the system before the change to that after. The interaction term in equation (4.6) allows the law dummy to change the response to change in transactions or house prices.

State fixed effects, $\mu_{i}$, that were differenced out of equations (4.3) and (4.4) have been added back in equation (4.6). This is because the law it variables introduce another difference to the VAR system. 
The state fixed effects in equation (4.6) hold constant any omitted second-differenced state-level variable that might shift the constant of the VAR system given by equation (4.4). This differencing aspect of equation (4.6) makes it a powerful way to control unobserved variables and endogeneity: see discussion below.

Our interest focuses on equation (4.3) with the law variable:

$$
\Delta b k r S_{i t}=\gamma_{1}+\beta_{1} \Delta b k r S_{i t-s}+\beta_{2} \Delta H P I_{i t-s}+\beta_{3} \Delta \operatorname{Trans}_{i t-s}+\alpha_{t} D_{t}+\alpha_{2} \Delta \operatorname{law}_{i t}+\alpha_{3} \Delta \operatorname{law}_{i t} \Delta \operatorname{Trans}_{i t-s}+\mu_{i}+\Delta \varepsilon_{i t}
$$

Here the change in law dummy is interacted with change in transactions; likewise it can be interacted with change in HPI.

All of our law change dummies are coded so that a one indicates a change expected to promote unbundling of brokerage services. As discussed above, these changes are 1) allowing minimum services to be waive or allowing non-agency and 2) rescission of anti-rebate laws. A third law variable is a change allowing either one of these two. In all cases, we expect a law change to reduce change in full-service brokers as discussed above: $\alpha_{2}<0$.

One issue with equation (4.7) is whether some omitted variable drives change in house prices, transactions and full service brokers. Changes in technology, income, the population age distribution or preferences for rental vs. ownership might be influential, but these are likely to change slowly whereas our model is based on differences. Our model is based on the findings of previous literature, and we do not find previous discussion of other variables plausibly related in annual change form. Moreover, VAR is agnostic about theory, relying on own-lags, predictive correlations 
and tests for the absence of correlations as a necessary condition for exogeneity. One of the strengths of VAR is that one might be surprised to find any significant coefficients other than the own-AR coefficients, $\beta_{1}$ in equation (4.7).

\section{Pre-existing Trends as a Control for Endogeneity and Heterogeneity}

A further concern is existence of state-specific trends in the data, a source of time-varying endogeneity and heterogeneity. The sample of states that have these changes is unlikely to be random. Using an annual panel of states, Wolfers (2006) pointed out in the context of divorce laws that differences-in-differences estimates may confound the stock-flow dynamics with panel-specific trends. Specifically, in our context, the real estate brokerage laws are outcomes of intense regulatory debate and lobbying processes. Figure 3 demonstrates a possible effect of pre-existing trend on the estimates. The response to a legal change (rescission of anti-rebate laws are illustrated in Figure 3) would affect the number of full service brokers but the effect may be overstated if the trend is not accounted for as a counterfactual. ${ }^{28}$ Without an effective control for such pre-existing trends, the estimates may be systematically biased.

[Insert Figure 3 here]

Figure 3 demonstrates the way we used pre-existing trends at the state level as a counterfactual to adjust the number of full service brokers after a legal or regulatory change. ${ }^{29} \mathrm{We}$ only include a linear trend as our model is already in changes. We expect that after controlling for pre-existing trends, we would find a consistent estimate of the legal changes. We introduce pre-existing trends as a robustness check on models that do not adjust for these trends.

\footnotetext{
28 Additionally, Figure 3 illustrates very different full service patterns by state over time.

${ }^{29}$ Waivable minimum service and non-agency changes were adjusted for pre-existing trends in the same way as rescission of anti-rebate laws.
} 


\section{Endogeneity of Law Changes}

In addition to the concern of pre-existing trends, a large number of political, institutional and regulatory features might facilitate the law changes we study. However, the issue here is whether the second difference for law changes in the VAR system (4.6) is influenced by endogeneity. Any attempt to argue that endogeneity is present would need to propose some mechanism whereby the VAR relationships feedback onto the law variables.

To further control for possible endogeneity in law adoption, we use multiple lags for instruments in generalized method of moments (GMM) estimators and test for over-identification, as well as Arellano and Bond (1991) dynamic panel (DP) methods. We will implement a simpler two stage least squares model as a further robustness check on possible endogeneity of laws. These latter methods and tests will be introduced as additions to ordinary least squares estimation of the dynamic differences-in-differences model given by equation (4.7), with and without controlling for preexisting trends.

\section{Variable Specification and Data Description}

In our empirical analysis, we first test our VAR model with data over 1984-2012 for all fifty states and the District of Columbia. We then determine whether VAR parameters are robust when we limit the time period to 2000-2012 (663 observations) where we have data on law changes.

The number of full service brokers as measured by membership in the National Association of Realtors (NAR) is the numerator of $b k r s_{i t}{ }^{30}$ We complete the VAR system (4.4) with volume of

\footnotetext{
30 An alternative source of information, number of licensees from the Association of Real Estate Licensing Law Officials (ARELLO) contains many discrepancies and recent information is missing for many states. After working with these data, we decided to focus on NAR brokers.
} 
housing transactions from NAR and the purchase-only quarterly Housing Price Index (HPI) by the Federal Housing Finance Agency (FHFA). We take the average year-over-year rate of change for the year. Data used for other variables are obtained from the US Census Bureau, and US Bureau of Economic Analysis. Table 1 presents descriptive statistics for the variables used in our analysis with their definitions and sources.

[Insert Table 1 here]

Our system (4.6) has transactions as an explanatory variable in order to provide a flexible representation of the time series relationship between brokers and units of service as represented by transactions. We control changes in NAR's share of total licensees by matching NAR brokers with NAR transactions. ${ }^{31}$

Units of services provided by full service brokers are introduced with three definitions of our dependent variable, $b k r S_{i t}$ (1) number of NAR members, with services controlled by transactions on the right hand side; (2) number of NAR members per capita; (3) number of NAR members divided by total state income. A novel aspect of our empirical framework is the use of population and income to measure units of service. Those that do not transact at any given time still have a demand for real estate brokers because brokers provide liquidity to their homes. After 2007, many people wanted to sell their houses, but their reservation prices were above transactions prices, producing a pent-up desire to sell. The use of number of people or dollar income to measure service demand (i.e., in the denominator of brokers per unit service, $b k r S_{i t}$ ) is analogous to measuring birth rates per 1000 women of child bearing age - as opposed to dividing by those actively trying to conceive.

\footnotetext{
${ }^{31}$ We analyzed 20 states with time series information on NAR brokers and total number of licensees. The mean (median) percentage of licensees that are NAR members was 47.5\% (47.6\%) with a standard deviation of about $10 \%$. The pattern of change over time in NAR membership percentages was remarkably uniform across the states, suggesting that the time dummies in our models will capture most variation in NAR membership penetration over time.
} 


\section{Results and Analysis}

\section{Panel VAR Models (Table 2)}

Table 2 reports results for the entire 1984-2012 time period to test our VAR framework. We remove extreme values (only 6) of the dependent variable. All models are estimated with a GMM specification. The variables are de-meaned to remove state-level unobserved heterogeneity. Robust standard errors are used to obtain t-statistics. Three equations are reported under our three different brokerage service measures.

We find strong support for the hypothesis that the cost of a given level of services is positively related to lagged house prices. The first-lagged house price growth is positive and statistically significant for all three measures of full service brokers per unit service. Moreover, the response of brokers to the first lagged house price change is also quite robust across the three specifications: elasticities range from 0.21 to 0.26 . Overall, summing over two lags, we find the elasticities ranging from 0.18 to 0.22 for the broker equations. This provides the first confirmation of wasteful competition under the minimal assumptions required by VAR. This is a strong result given that we have differenced the data at the state level and controlled for autoregressive relationships within changes for full service brokers. Unsurprisingly, we find statistically significant and positive predictive power for transaction volume (models (1), (4) and (7)), as required in order to control for levels of services provided by NAR brokers and any change in NAR market penetration. The strong positive and robust relationship between the second lag in house prices and transactions volume, compared to the zero effect of the second lag on other variables in the system, suggests that house prices influence brokers before they influence transactions: i.e., the dynamics of wasteful competition are quite complex.

[Insert Table 2 here] 
We find that changes in full service brokers Granger cause changes in house prices and that the point estimate of the elasticity ranges from about .16 to .18 in the different specifications, whereas transactions do not respond significantly to brokers in models (3) and (6). Also, the transactions variable positively predicts house prices with similar elasticities. The negative relationship between change in brokers per dollar income and change in transactions (Table 2, model 9), compared to insignificant relationships in models (3) and (6), suggest greater use of full service brokers when income increases, a finding new to this study. These results suggest that it is inadvisable to rely on assumptions of exogeneity among these three variables if using a structural model.

State Fixed Effect Models (Tables 3 and 4a-4c)

In table 3, we estimate the single equation model given by equation (4.3). We use state dummies to allow changes in the dependent to have different intercepts in each state. This tests the VAR for robustness and allows introduction of law dummies in the next table.

[Insert Table 3 here]

Transactions volume is a necessary variable as suggested by $\mathrm{HH}$ and our equation (4.3); also, it controls for any changes in NAR marketing not captured by the time dummies. This is confirmed by comparing table 3 regressions; the sum of coefficients on lagged changes in house prices is 0.07 in regression two as opposed to 0.25 in regression three and similar results are found when comparing regression five with six and eight with nine. The preferred specifications, which pair NAR brokers with transactions by those brokers, strongly confirm a positive relationship between number of brokers and transactions as suggested by free entry. 
Compare Table 3, regression 3 with Table 2, regression 1 . The coefficients on the house price variables are virtually identical and the transactions coefficients are both strongly significant and in the 0.15-0.27 range. We conclude that the state FE method closely approximates the full VAR system and that only one lag is needed. Similar conclusions are supported when we use brokers per capita and brokers per dollar income as the dependent variables.

After testing that the basic hypothesis holds true with a long time series (1984-2012), we move on to testing regulatory interventions, where data are only available for 13 years (2000-2012). All regressions in Tables 4a-4c include a global financial crisis (GFC) dummy variable which equals one in 2007, 2008 and 2009, otherwise zero. ${ }^{32}$ The GFC dummy has the expected negative sign. Coefficients on first-lagged house price changes and transactions changes remain positive over the shorter time period. Reduced levels and significance for elasticity of brokers with respect to house prices in some models is likely due to the short time series, strong positive correlation with transactions (see Table 2) and downward bias due to the omission of hours worked. Interestingly, the better control for services in Table $4 \mathrm{c}$ increases significance levels for this elasticity, and the point estimates ( 0.15 to 0.18 ) are consistent with those in Table 3 . We conclude that the model is generally robust to the short time series available to test law changes.

[Insert Tables 4a-4c here]

Changes to waivable minimum service and laws permissive of non-agency ( $\Delta$ law 1$)$ have significant negative effects, confirming the hypothesis that they encourage unbundling of services and reduce the costs associated with full service brokers. Pre-existing trends do not have an important influence on the effect of unbundling laws (results not shown). However the effect of waivable provisions and

\footnotetext{
32 Annual US real GDP peaked in 2007 and troughed in 2009. NBER business cycle dates are December 2007 (peak) March 2009 (trough). Finally, Figure 2 shows 2007 as the first year of decline in brokers in most states.
} 
non-agency changes is not robust to adding time dummy variables in any of Tables $4 \mathrm{a}-4 \mathrm{c}$. Appendix tables A1 and A2 suggest that this is due to clustering in time: many of these changes occurred in 2006. I.e., any effect of regulatory change on brokerage costs is captured by the time and GFC dummy variables in the short time series available.

Rescission of anti-rebate laws and regulations (4law2) have strong and significant negative effects on change in NAR members: rescission decreases the annual growth in full service brokers by more than $4.7 \%$ per year in all specifications with time fixed effects. In preferred specifications (Table 4c), where services are measured by income and with pre-existing trends as the counterfactual, the effect rises to $6.0 \%$ per year. This is not surprising in light of Figure 3, which shows significant pre-existing trends in some states. It is not necessary to choose between these models in order to conclude that anti-rebate laws are important barriers to unbundling of brokerage services.

Further evidence on the effect of time clustering is provided when all three legal and regulatory changes are combined in $\Delta$ law3, a variable with changes in 18 states and in years ranging from 20052010. The magnitude and significance of this coefficient is robust across alternative specifications of the model in the three tables. A law change reduces the growth of full service brokers by over 2 percentage points per year.

\section{Dynamic Panel Models (Table 5)}

The purpose of the dynamic panel models in Table 5 is to evaluate robustness to three key concerns discussed in sections 2 and 4: heteroscedasticity, serial correlation, and endogeneity. As standard in the econometric literature, we present a range of models that differ in terms of number of lagged instruments and correction for heteroscedasticity, and perform one-step robust generalized method 
of moments (GMM) estimation in first-differences. To test for serial correlation, we perform Arellano-Bond tests. Table 5 shows that the $p$-values of $\mathrm{AR}(1)$ and $\mathrm{AR}(2)$ tests. We reject the null hypothesis of no first-order auto-correlation for all models at the 5 percent significance level. The null hypothesis of no second order auto-correlation is not rejected for first two dependent variables. All five of these results confirm the model. For the third dependent variable (weighted by per capita income), we reject the null hypothesis. ${ }^{33}$

[Insert Table 5 here]

The dynamic panel GMM estimator uses multiple lags as instruments and thus a test of overidentification is recommended. We perform the Hansen test that yields a J-statistic under the null hypothesis that instruments are exogenous. By default, the model uses all available lags as instruments. The results in Table 5 reassure our concern about endogeneity and serial correlation: the lagged dependent variables are important and significant inclusions in our models. The elasticities of brokers to first-lagged house price change are similar to Table 4 with time and state fixed effects. Most importantly, the sizes of the coefficients on the regulatory interventions are about the same as the estimates in Tables $4 \mathrm{a}-4 \mathrm{c} .{ }^{34}$ This suggests that our conclusions from Table 4 are robust to additional testing for endogeneity, serial correlation and unobserved heterogeneity.

\section{Further Robustness Tests and MSA-level Regressions (Table 6)}

We conducted additional two stage least squares tests (not shown) designed to control for endogeneity. The first stage estimates which states are likely to adopt law change based on industry strength. The strength of industry influences on real estate boards is computed as number of

\footnotetext{
33 We included the inverse of lagged income in some models (not shown). This eliminated significance for AR(2) and results on the law variables are broadly similar to Table 5 .

34 None of the models we tested show significant interactions of law changes with any other variable.
} 
industry members on the regulatory board. The second stage is the same as the regressions in Table 4, except that the law variables are replaced by values predicted in the first stage. Results confirm findings for the rebate and waivable variables.

Furthermore, a key concern in all empirical modelling that we have conducted so far is that housing markets are essentially 'local': i.e. metro-level variation within a state is a significant source of heterogeneity. A significant challenge for us is that we do not have MSA-level data on number of brokers and transactions. Therefore, we respond to this concern with a regression-based partitioning of the state-level data to derive MSA-level information. Specifically, we use population (a demand shifter), building permits (a supply shifter) and the fixed effects to predict the state-level brokers and transaction information within a constrained regression where the coefficients of the demand and supply shifters sum to unity. Since we have the MSA-level data on the demand and supply shifters, we can then use the same coefficients and share of fixed effects to calculate the MSA-level information on number of brokers and transactions. Note that for multi-state MSAs, we apportion the variables according to the state shares. ${ }^{35}$

With the derived information on number of brokers and transactions, we then perform exactly the same model specifications as in Tables 4 and 5: see results in Table 6, where we have 4,187 MSA years for the fixed effects model and 3,805 MSA years for the dynamic panel model where lags use the initial year. The results support wasteful competition; the coefficient on change in house prices is always positive and significant. The size of the coefficient is smaller than the state-level fixed effects model and about equal to the state dynamic panel model. We conclude that between $8 \%$ and $10 \%$ of

\footnotetext{
35 An appendix available on request contains details on each step: 1) the two state level constrained regressions on population and building permits (brokers and transactions are the dependent variables); 2) summary statistics for MSA level data on population, building permits and the derived information on brokers and transactions; 3 ) a list of multistate MSAs and the state shares used for allocating derived MSA data.
} 
any increase in house prices results in wasteful increases in number of brokers on average across all MSAs.

Turning to the law dummies, all coefficients are larger in absolute value and more significant at the MSA level. This confirms our earlier conclusion that we obtain conservative estimates of the effect of law change on the cost of brokerage services. For all 18 law changes, we now conclude that the changes resulted in an average 3.5 percentage points per year reduction in growth of full service brokers.

The dynamic panel regressions in Table 6 indicate significant positive interactions between change in lagged transactions and the law dummies. It is plausible that more rapid growth in transactions would mute the effect of law change by encouraging full service brokers despite the less accommodating legal environment. The amount of this effect can be evaluated at the sample mean which is about $+2.5 \%$ per year change in transactions; i.e., we multiply 2.5 times the interaction coefficient and add to the coefficient on the law change dummy. For $\Delta$ law 1 the net effect of the law change is $-2.3 \%$ per year. For $\triangle \operatorname{law} 2(\Delta \operatorname{law} 3)$ the net effect of the law change is $-6.2 \%(-4.7 \%)$. The $\Delta$ law3 interaction has the smallest standard error and the net negative effect is still strongly negative $(-2.4 \%)$ at the $75^{\text {th }}$ percentile of transactions change $(8.9 \%$ per year). Overall, Table 6 indicates that our approach to modelling the effect of legal changes is robust to MSA-level heterogeneity.

\section{Conclusions}

National Association of Realtor (NAR) brokers are a proxy for the cost of full services because brokers are typically $60-70 \%$ of operating costs and because NAR policies have catered to full service firms as indicated by the 2008 settlement of a suit brought by the DOJ. Consequently, we 
approximate changes in full service costs with percentage changes in number of full service brokers. Starting with the structural cost model of Han and Hong (2011), we develop a reduced form model in an annual state-level panel vector autoregressive (VAR) system pairing number of NAR brokers with service levels as indicated by number of NAR transactions, population and income. Changes in laws facilitating less than full services are introduced as quasi-natural events causing reductions in costs. We use differences-in-differences (DID), adjustment for pre-existing trends, dynamic panel models, and two stage least squares to control for endogeneity, unobserved heterogeneity and serial correlation.

Our findings using data for 1984-2012 support the wasteful competition hypothesis of a positive relation between house price change and change in full service brokers after controlling for number of transactions: i.e., wasteful competition is confirmed when analyzed with VAR, DID and dynamic panel methods. Given that all variables are annual changes after subtracting state fixed effects, it is unlikely that some omitted variable (e.g., demographic changes) account for our findings. ${ }^{36}$ The predictions of the model are robust when cost per unit of service is specified as change in brokers per capita or as change in brokers per dollar income.

Our main findings may be summarized as follows:

- Using a dummy for the twelve states that changed to allow minimum services to be waived or non-agency to be substituted, we produce evidence that these changes, like the rescission of anti-rebate laws, tended to reduce the cost of brokerage services by encouraging unbundling. However, results are not robust to yearly time dummies because of the clustering of regulatory changes in the middle of the 2000's.

\footnotetext{
${ }^{36}$ Our results indicate complex dynamic interactions among brokers, house prices and transactions; these support the minimal assumptions required by our panel VAR framework.
} 
- Results for the anti-rebate dummy confirm the findings of Han and Hong (2011): change in full service brokers per unit service responds negatively to rescission of an anti-rebate law. Our preferred estimates (Tables 5 and 6) suggest that rescission reduces growth of full service brokers by between 4 and 6 percentage points per year, on average across all states and MSAs. This result is robust to several alternative specifications and to various controls for endogeneity, including state-specific pre-existing trends.

- Combining all law changes encouraging unbundling (eighteen states with changes taking effect from 2005 through 2010) indicates a strong negative effect on the number of full service brokers. The average effect is a reduction of more than 2 percentage points per year in growth of full service brokers and MSA-level regressions suggest net effects averaging between 3.5 and 5 percentage points per year. This is robust to annual time dummies and to several alternative specifications and econometric models.

Our analysis provides a robust methodological framework of analyzing similar public policies. We develop a method for allocating state level variables to MSAs by using time series available at both levels with constrained regressions. With the derived information on number of brokers and transactions at the MSA level, results lend significant support to the state-level interpretations implying that the effect of legal changes is robust to MSA-level heterogeneity.

Authors would like to thank the editor, A. Yavas, two anonymous referees, J. Beck, L. Han, S-H. Hong, A. Yelowitz and L. Zumpano for helpful comments. 


\section{References}

Anderson, R., D. Lewis and L. Zumpano. 2000. Residential Real Estate Brokerage Efficiency from a Cost and Profit Perspective. Journal of Real Estate Finance and Economics 20: 295-310.

Arellano, M. and S. Bond. 1991. Some Tests of Specification for Panel Data: Monte Carlo Evidence and an Application to Employment Equations. Review of Economic Studies 58: 277-97.

Arellano, M. and O. Bover. 1995. Another Look at the Instrumental Variables Estimation of Error Components Models. Journal of Econometrics 68: 29-51.

Baltagi, B. 2008. Econometric Analysis of Panel Data, 4th Edition. Wiley: Chichester.

Barwick, P. J. and Pathak, P. A. (2015) The Costs of Free Entry: an Empirical Study of Real Estate Agents in Greater Boston. Rand Journal of Economics 46(1): 103-145.

Bates, L.J. and R.E. Santerre. 2013. Does the U.S. Health Care Sector Suffer from Baumol's Cost Disease? Evidence from the 50 states. Journal of Health Economics 32(2): 386-391.

Beck, J., F. Scott and A. Yelowitz. 2012. Concentration and Market Structure in Local Real Estate Markets. Real Estate Economics 40(3): 422-460.

Benjamin, J.D., P. T. Chinloy and D. T. Winkler. 2009. Labor Supply, Flexible Hours and Real Estate Agents. Real Estate Economics 37(4): 747-767.

Cetorelli, N. and P. Strahan. (2006). Finance as a Barrier of Entry: Bank Competition and Industry Structure in Local U.S. Markets. Journal of Finance 61(1): 437-461.

Federal Trade Commission and U.S. Department of Justice ("FTC-DOJ"). 2007. Competition in the Real Estate Brokerage Industry, Report by the Federal Trade Commission and U.S. Department of Justice. Retrieved from https://www.ftc.gov/sites/default/files/documents/reports/competition-real-estate-brokerage-industryreport-federal-trade-commission-and-u.s.department-justice/v050015.pdf.

Jia, P. and P. Pathak. 2010. The Impact of Commissions on Home Sales in Greater Boston. American Economic Review: Papers \& Proceedings 100: 475-479.

Government Accountability Office. 2006. Real Estate Brokerage: Various Factors May Affect Price Competition, Report to the Subcommittee on Housing and Community Opportunity, Committee on Financial Services, House of Representatives (\#GAO-06-1005T). Retrieved from http://www.gao.gov/assets/120/114540.html.

Hsieh C. and E. Moretti. 2003. Can Free Entry be Inefficient? Fixed Commissions and Social Waste in the Real Estate Industry. Journal of Political Economy, 111(5): 1076-1122.

Han, L. and S. H. Hong. 2011. Testing Cost Inefficiency Under Free Entry in the Real Estate Brokerage Industry. Journal of Business and Economic Statistics, 29(4): 564-578.

Hendel, I., A. Nevo and F. Ortalo-Magné. 2009. The Relative Performance of Real Estate Marketing Platforms: MLS versus FSBOMadison.com. American Economic Review 99(5), 1878-98.

Jayaratne, J. and P. Strahan. 1996. The Finance-Growth Nexus: Evidence from Bank Branch Deregulation. Quarterly Journal of Economics 111(3), 639-670. 
Johnson, R.C. and S. Raphael. 2009. The Effects of Male Incarceration Dynamics on AIDS Infection Rates among African-American Women and Men. Journal of Law \& Economics, 52(2): 251-293.

Levitt, S. and C. Syverson. 2008. Antitrust Implications of Home Sellers Outcomes When Using Flat-Fee Real Estate Agents. Brookings-Wharton Papers on Urban Affairs, 47-93.

Miceli, T. J. 1992. The Welfare Effects of Non-Price Competition Among Real Estate Brokers., Journal of the American Real Estate and Urban Economics Association 20(4), 519-532.

Rutherford, R., and A. Yavas. 2012. Discount Brokerage in Residential Real Estate Markets. Real Estate Economics, 40(2).

Turnbull, G.K. 1996. Real Estate Brokers, Nonprice Competition and the Housing Market. Real Estate Economics. 24(3): 293-316.

Wiley, J.A., L.V. Zumpano and J.D. Benefield. 2011. The Limited-Service Brokerage Decision: Theory and Evidence. Journal of Real Estate Finance and Economics 43(3): 336-358.

Wolfers, J. 2006. Did Unilateral Divorce Laws Raise Divorce Rates? A Reconciliation and New Results, American Economic Review, 96(5): 1802-1820.

Woodall, P. and S. Brobeck. 2006. State Real Estate Regulation: Industry Dominance and Its Consumer Costs. Consumer Federation of America. Retrieved from http://www.consumerfed.org/elements/www.consumerfed.org/file/housing/CFA Real Estate Commissio ner Report.pdf.

Yavas, A. 1992. A Simple Search and Bargaining Model of Real Estate Markets. Journal of the American Real Estate and Urban Economics Association, 20(4): 533-548.

Yavas, A. and P. Colwell. 1999. Buyer Brokerage: Incentive and Efficiency Implications, Journal of Real Estate Finance and Economics, 18(3): 259-277.

Yinger, J. 1981. A Search Model of Real Estate Broker Behavior. American Economic Review, 71(4): 591-605.

Zumpano, L.V., H. W. Elder and G.E. Crellin, G.E. (1993). The Market for Real Estate Brokerage Services: Cost of Production and Economies of Scale. Journal of Real Estate Finance and Economics, 6: 237-250. 
Appendix: Summary of Selected Law Changes in 50 States and District of Columbia

\section{Table A1: States with Waivable Minimum Service Laws}

\begin{tabular}{|c|c|c|c|c|}
\hline State & $\begin{array}{l}\text { Non- } \\
\text { Agency? }\end{array}$ & $\begin{array}{l}\text { Waive } \\
\text { Year }\end{array}$ & Law & Summary \\
\hline Delaware & & $\begin{array}{l}2006 \\
\text { revised } \\
\text { in } 2011\end{array}$ & 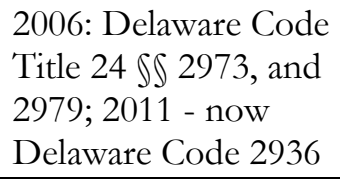 & $\begin{array}{l}2006 \text { - common law of agency abrogated; unless not authorized (waivable), } \\
\text { broker must be reasonably available to client to accept offers, assist in } \\
\text { negotiating, and answer questions. } 2011 \text { - law entirely rewritten, includes duty } \\
\text { to cooperate with other brokers if client authorizes (waivable) }\end{array}$ \\
\hline Michigan & pre- 2000 & 2008 & $\begin{array}{l}\text { Michigan Compiled } \\
\text { Laws } \int 2512 \mathrm{~d} \text {; } \\
\text { Michigan } \\
\text { Administrative Code, } \\
\text { R 339.22307 }\end{array}$ & $\begin{array}{l}\text { Statute requires a broker to accept and present offers, assist in negotiating, and } \\
\text { furnish a closing statement; these services can be waived in a limited service } \\
\text { agreement. } \\
\text { Administrative regulation require that a licensee promptly deliver all offers and } \\
\text { other documents, and shall make certain that all terms and conditions of the } \\
\text { real estate transaction are included in the offer to purchase. } \\
\text { Statutes allow waiver; regulations do not. }\end{array}$ \\
\hline Montana & pre-2000 & 2009 & $\begin{array}{l}\text { Montana Code } \\
\text { Annotated \$ } 37-51- \\
313(12)\end{array}$ & $\begin{array}{l}1995 \text { - Licensees must "endeavor to ascertain all pertinent facts concerning } \\
\text { each property in any transaction in which the licensee acts" so the licensee can } \\
\text { fulfill the his or her obligation to avoid error, exaggeration, misrepresentation, } \\
\text { or concealment of pertinent facts; May } 2009 \text { - added waivable minimum } \\
\text { services (participate in negotiations, obtains signatures on and submit offers), } \\
\text { on offers, via Board Realty Regulation } 24.210 .641 \text {. }\end{array}$ \\
\hline Nevada & & 2007 & $\begin{array}{l}\text { NRS 645.254; } \\
\text { Regulations T645-02 }\end{array}$ & $\begin{array}{l}\text { In } 2007 \text {, regulations defined duty to present offers as requiring minimum } \\
\text { services, but statute enacted in same year making it waivable. Requirement that } \\
\text { presenting offers was defined as accepting and delivering offers and } \\
\text { counteroffers, answering questions about offers and counteroffers, and } \\
\text { assisting in negotiating. }\end{array}$ \\
\hline $\begin{array}{l}\text { New } \\
\text { Mexico }\end{array}$ & pre-2000 & 2006 & $\begin{array}{l}\text { New Mexico } \\
\text { Administrative Code } \\
\text { 16.61.19.8(D) }\end{array}$ & $\begin{array}{l}\text { Broker must present offers in a timely manner and assist with completing the } \\
\text { transaction; these services can be waived; broker must disclose waiver to the } \\
\text { other brokers involved in the transaction }\end{array}$ \\
\hline Ohio & & 2006 & $\begin{array}{l}\text { Ohio Revised Code } \\
\text { Title XLVII } \\
\text { S\$4735.621, } 4735.63 \\
\text { and } 4735.65\end{array}$ & $\begin{array}{l}\text { Licensees must accept and present offers, answer questions, assist in } \\
\text { negotiating; these services can be waived. }\end{array}$ \\
\hline
\end{tabular}




\begin{tabular}{lcll}
\hline Tennessee & pre-2000 2006 & $\begin{array}{l}\text { Tennessee Code } \\
\text { Annotated } \$ 62-13- \\
404\end{array}$ & $\begin{array}{l}\text { Unless specifically in writing (meaning waivable) a licensee must schedule } \\
\text { property showings, receive offers, answer questions, and provide advice. }\end{array}$ \\
\hline Virginia & 2006 & $\begin{array}{l}\text { Virginia Code \$54.1- } \\
2130-2134\end{array}$ & $\begin{array}{l}\text { Prior to 2006 - requirement to present all written offers and counteroffers in a } \\
\text { timely manner, even after the property is under contract; 2006 - minimum } \\
\text { services required (assisting, presenting, negotiating) but can be waived if broker } \\
\text { hired as independent contractor. }\end{array}$ \\
\hline Wisconsin & 2006 & $\begin{array}{l}\text { Wisconsin Statute } \\
542.133(6)\end{array}$ & $\begin{array}{l}\text { A broker providing brokerage services owes certain waivable duties, including a } \\
\text { duty to negotiate on behalf of the client. }\end{array}$ \\
\hline Total & $\mathbf{9}$ & &
\end{tabular}

Sources: DOJ website, ARELLO, state statues and regulation, state public acts and bills, commission websites, media articles

Notes: A review of the 51 state brokerage statues and regulations was conducted to determine whether a state had any provisions that could be interpreted as having a minimum service requirement that was subsequently modified to allow the requirement to be waived. We did not consider the requirement of timeliness to be sufficiently binding to be counted as a minimum service requirement. There are nine states that allow waivable minimum services as of December 2012. WAIVE gives the year the requirements became waivable and therefore not binding. NONAGENCY are states allow non-agency relationships; in all cases there was no change after 2000, which implies that the waivable provision further encouraged unbundling of services. See Table A2 for details on nonagency. Sources: Media articles, state commission websites, state public acts and bills, state statutes and regulations, DOJ website and the Association of Real Estate Licensing Law Officials (ARELLO). 
Table A2: States with Non-Agency Laws

\begin{tabular}{|c|c|c|c|c|}
\hline State & $\begin{array}{l}\text { Non-Agency } \\
\text { Enacted }\end{array}$ & $\begin{array}{l}\text { Non-Agency } \\
\text { Label }\end{array}$ & Law & Summary \\
\hline Alabama & pre-2000 & Contract Broker & $\begin{array}{l}\text { Alabama Code } \int \\
34-27-81(17)\end{array}$ & $\begin{array}{l}\text { Real estate licensee assists one or more parties, who are } \\
\text { customers, in a contemplated real estate transaction, without } \\
\text { being the agent, fiduciary, or advocate of that party to the } \\
\text { transaction. }\end{array}$ \\
\hline Colorado & pre-2000 & Transaction Broker & $\begin{array}{l}\text { Colorado Revised } \\
\text { Statute } \int 12-61-802 \\
(6)\end{array}$ & $\begin{array}{l}\text { In the absence of a signed agreement regarding the brokerage } \\
\text { relationship, the default position under Colorado License Law is } \\
\text { "transaction-brokerage". }\end{array}$ \\
\hline Florida & pre-2000 & Transaction Broker & $\begin{array}{l}\text { Florida Statute } \int \\
475-278(2)\end{array}$ & $\begin{array}{l}\text { Presumed that all licensees are operating as transaction brokers } \\
\text { unless a single agent or no brokerage relationship is established. } \\
\text { A transaction broker provides a limited form of representation } \\
\text { to a buyer, a seller, or both in a real estate transaction but does } \\
\text { not represent either in a fiduciary capacity or as a single agent. }\end{array}$ \\
\hline Georgia & pre-2000 & Transaction Broker & $\begin{array}{l}\text { Official Code of } \\
\text { Georgia Annotated } \\
\text { Title } 10, \text { Chapter } \\
6 \mathrm{~A}\end{array}$ & $\begin{array}{l}\text { Broker who has not entered into a client relationship with any } \\
\text { of the parties to a particular real estate transaction and who } \\
\text { performs only ministerial acts on behalf of one or more of the } \\
\text { parties. }\end{array}$ \\
\hline Idaho & pre-2000 & Nonagent & $\begin{array}{l}\text { Idaho Statutes } \int 54- \\
2083(13)\end{array}$ & Broker working with or assisting a buyer or seller as a customer. \\
\hline Kansas & pre-2000 & Transaction Broker & $\begin{array}{l}\text { Kansas Statues } \\
\text { Annotated } \int 58- \\
30,113\end{array}$ & $\begin{array}{l}\text { A broker engaged as a transaction broker is not an agent for } \\
\text { either party. }\end{array}$ \\
\hline Kentucky & pre-2000 & Transaction Broker & $\begin{array}{l}201 \text { Kentucky } \\
\text { Administrative } \\
\text { Code 11:400 }\end{array}$ & $\begin{array}{l}\text { Broker assists the parties to a potential real estate transaction in } \\
\text { communication, interposition and negotiation, to reach an } \\
\text { agreement among or between them, without acting as agent for } \\
\text { any party; both parties are treated as customers. }\end{array}$ \\
\hline Maine & 2005 & Transaction Broker & $\begin{array}{l}\text { Maine Revised } \\
\text { Statutes } \$ 13283\end{array}$ & $\begin{array}{l}\text { Broker does not represent any party as a client to a real estate } \\
\text { transaction }\end{array}$ \\
\hline
\end{tabular}




\begin{tabular}{|c|c|c|c|c|}
\hline Massachusetts & 2005 & Facilitator & $\begin{array}{l}254 \text { Code of } \\
\text { Massachusetts } \\
\text { Regulations } 3.00 \\
(13)(e)\end{array}$ & $\begin{array}{l}\text { Facilitator works to complete the transaction. Although bound } \\
\text { by license law and MGL Ch. } 93 \mathrm{~A} \text {, they do not have a fiduciary } \\
\text { relationship with the seller or the buyer. They do not represent } \\
\text { either party in the transaction. }\end{array}$ \\
\hline Michigan & pre-2000 & $\begin{array}{l}\text { Transaction } \\
\text { Coordinator }\end{array}$ & $\begin{array}{l}\text { Michigan Compiled } \\
\text { Laws } \int 339.2517 \\
(11)(\mathrm{k})\end{array}$ & $\begin{array}{l}\text { A licensee who is not acting as the agent of either the buyer or } \\
\text { the seller. }\end{array}$ \\
\hline Missouri & pre-2000 & Transaction Broker & $\begin{array}{l}\text { Missouri Revised } \\
\text { Statues } ₫ 339.755\end{array}$ & $\begin{array}{l}\text { A real estate licensee may provide real estate service to any party } \\
\text { in a prospective transaction without an agency or fiduciary } \\
\text { relationship to one or more parties to the transaction }\end{array}$ \\
\hline Montana & pre-2000 & Statutory Broker & $\begin{array}{l}\text { Montana Code } \\
\text { Annotated } \int 37-51- \\
102 \text { and } 313\end{array}$ & $\begin{array}{l}\text { A licensee who assists one or more of the parties in a } \\
\text { transaction, but does not represent any party as an agent. A } \\
\text { licensee is presumed to be acting as a "statutory broker" unless } \\
\text { they have entered into a listing agreement with the SELLER, a } \\
\text { BUYER-broker agreement with the BUYER, or a dual agency } \\
\text { agreement with all parties. }\end{array}$ \\
\hline $\begin{array}{l}\text { New } \\
\text { Hampshire }\end{array}$ & 2008 & Facilitator & $\begin{array}{l}\text { New Hampshire } \\
\text { Revised Statutes } \\
\text { Annotated } \int 331- \\
\text { A:25-f }\end{array}$ & $\begin{array}{l}\text { Licensee who assists one or more parties during all or a portion } \\
\text { of a real estate transaction without being an agent or advocate } \\
\text { for the interests of any party. }\end{array}$ \\
\hline New Jersey & pre-2000 & Transaction Broker & $\begin{array}{l}\text { New Jersey Statutes } \\
\text { Annotated 45:15-1 } \\
\text { et seq.; Real Estate } \\
\text { Commission } \\
\text { Regulations 11:5- } \\
6.9\end{array}$ & $\begin{array}{l}\text { The New Jersey Real Estate License Law and the administrative } \\
\text { rules promulgated thereunder do not mandate that licensees } \\
\text { must act as agents when rendering real estate brokerage services. } \\
\text { Transaction broker defined in state regulations. }\end{array}$ \\
\hline New Mexico & pre-2000 & Transaction Broker & $\begin{array}{l}\text { New Mexico } \\
\text { Administrative } \\
\text { Code } \int 16.61 .19 .9 \\
\text { A }\end{array}$ & $\begin{array}{l}\text { Broker that provides real estate services without entering into an } \\
\text { agency relationship. The transaction broker relationship is a } \\
\text { non-fiduciary relationship. }\end{array}$ \\
\hline Oklahoma & 2000 & Transaction Broker & $\begin{array}{l}\text { Oklahoma Statutes } \\
\int 858-351,858-33\end{array}$ & $\begin{array}{l}\text { Broker who provides services by assisting a party in a } \\
\text { transaction without being an advocate for the benefit of that } \\
\text { party. }\end{array}$ \\
\hline Pennsylvania & pre-2000 & $\begin{array}{l}\text { Transaction } \\
\text { Licensee }\end{array}$ & $\begin{array}{l}\text { Pennsylvania Code } \\
\int 35.316\end{array}$ & $\begin{array}{l}\text { A licensee who is not acting as an agent or advocate for the } \\
\text { consumer. }\end{array}$ \\
\hline
\end{tabular}




\begin{tabular}{|c|c|c|c|c|}
\hline Rhode Island & pre-2000 & $\begin{array}{l}\text { Transaction } \\
\text { Facilitator }\end{array}$ & $\begin{array}{l}\text { Rhode Island } \\
\text { General Laws 5- } \\
20.6-2 \text { (23) }\end{array}$ & Does not owe any fiduciary duties to any party in a transaction. \\
\hline \multicolumn{5}{|l|}{ South Carolina } \\
\hline South Dakota & pre-2000 & Transaction Broker & $\begin{array}{l}\text { South Dakota } \\
\text { Codified Laws } \$ \\
\text { 36-21A-144 }\end{array}$ & $\begin{array}{l}\text { Required to perform the terms of any written agreement made } \\
\text { with the customer. }\end{array}$ \\
\hline Tennessee & pre-2000 & $\begin{array}{l}\text { Facilitator } / \text { Transac } \\
\text { tion Broker }\end{array}$ & $\begin{array}{l}\text { Tennessee Code } \\
\text { Annotated } \$ 62- \\
13-401\end{array}$ & $\begin{array}{l}\text { Until an agent enters into a specific written agency agreement to } \\
\text { establish an agency relationship with one or more parties to a } \\
\text { real estate transaction, an agency relationship shall not be } \\
\text { assumed, implied or created. }\end{array}$ \\
\hline Wyoming & pre-2000 & Intermediary & $\begin{array}{l}\text { Wyoming Statutes } \int \\
33-28-305\end{array}$ & Does not act as an agent or advocate for either party. \\
\hline TOTAL & 21 & & & \\
\hline
\end{tabular}


Table A3: States with Anti-Rebate Laws and Rescission of Anti-Rebate Laws

States, not listed here, never had an anti-rebate law

\begin{tabular}{|c|c|c|c|c|}
\hline State & $\begin{array}{l}\text { Anti- } \\
\text { Rebate } \\
\text { Enacted }\end{array}$ & $\begin{array}{l}\text { Anti- } \\
\text { Rebate } \\
\text { Rescinded }\end{array}$ & Law & Summary \\
\hline Alabama & pre-2000 & & Alabama Code $\int 34-27-36(a)(11) \&(12)$ & $\begin{array}{l}\text { Licensee may not pay or receive any rebate from any } \\
\text { person in a real estate transaction. }\end{array}$ \\
\hline Alaska & pre-2000 & & Alaska Statute $\iint 08.88 .401(\mathrm{~d}) \&(\mathrm{e})$ & $\begin{array}{l}\text { Licensee may not pay any part of a fee to an unlicensed } \\
\text { person, except paymets to client in resolution of a dispute. } \\
\text { However, as of } 2012 \text {, licensee may waive their commission } \\
\text { if they are selling property of a charity or donate a portion } \\
\text { of their commission to a charity. For purposes of our } \\
\text { analysis, we did not include Alaska as rescinding the anti- } \\
\text { rebate law because rebates still can not be given to buyers } \\
\text { or sellers. }\end{array}$ \\
\hline Iowa & pre-2000 & 2005 & Iowa Code $\ 543 \mathrm{~B} .60 \mathrm{~A}$ & $\begin{array}{l}\text { Prior to } 2005 \text {, rebates were not allowed. After } 2005 \text {, } \\
\text { rebates are allowed when there is only one broker involved } \\
\text { in a transaction (not if there are two or more brokers } \\
\text { involved in the same transaction). }\end{array}$ \\
\hline Kansas & pre-2000 & & Kansas Statute Annotated \$58-3062a3 & $\begin{array}{l}\text { Licensee cannot accept, give or charge any rebate or } \\
\text { undisclosed commission. }\end{array}$ \\
\hline Kentucky & pre-2000 & 2005 & $\begin{array}{l}201 \text { Ky. Admin. Reg. 11:011, Section } \\
\text { 1(5); } 201 \text { Ky. Admin. Reg. 11:121, } \\
\text { Section 1(2) }\end{array}$ & $\begin{array}{l}\text { Regulations formerly prohibited a broker from offering any } \\
\text { prize, money, free gift, rebate as an inducement. These } \\
\text { regulations were rescinded in } 2005 \text {. }\end{array}$ \\
\hline Louisiana & pre-2000 & & $\begin{array}{l}\text { Louisiana Revised Statutes Section } 145 \\
\text { (7) }\end{array}$ & Licensee cannot give a rebate. \\
\hline Mississippi & pre-2000 & & Miss. Code Ann. \ 73-35-21(1)(j)(2000) & $\begin{array}{l}\text { Licensee cannot pay any rebate, profit or commission to } \\
\text { any person other than another state licensee. }\end{array}$ \\
\hline Missouri & pre-2000 & & $\begin{array}{l}\text { Missouri Revised Statute } \$ \mathbb{S} \\
\text { 339.100.2(13) }\end{array}$ & $\begin{array}{l}\text { Licensee cannot use prizes, money, or gifts as inducement } \\
\text { to secure customers or clients. }\end{array}$ \\
\hline
\end{tabular}




\begin{tabular}{|c|c|c|c|c|}
\hline Montana & 2007 & 2008 & $\begin{array}{l}\text { Montana Board of Realty Regulation } \\
\text { Rule 24.210.641(5)(af) }\end{array}$ & $\begin{array}{l}\text { The Montana Board adopted anti-rebate law in } 2007 \text {, and } \\
\text { reversed it in 2008. Now, rebates are allowed and payment } \\
\text { to any principals or reducing the commission owed by any } \\
\text { principals is not considered payment of a commission to } \\
\text { an unlicensed person. For purposes of our analysis, we did } \\
\text { not include Montana as an anti-rebate state because the } \\
\text { anti-rebate law was not in effect long enough to allow for } \\
\text { lagged entry and exit. }\end{array}$ \\
\hline New Jersey & pre-2000 & 2010 & $\begin{array}{l}\text { http://www.state.nj.us/dobi/bulletins/ } \\
\text { blt10_03.pdf }\end{array}$ & $\begin{array}{l}\text { As of } 2010 \text {, broker can provide a rebate, but only to a } \\
\text { purchaser of residential real property. }\end{array}$ \\
\hline New York & & & & $\begin{array}{l}\text { There is some commentator disagreement about how to } \\
\text { interpret NY licensing laws; but commission website says } \\
\text { rebates are allowed. See } \\
\text { http://www.dos.ny.gov/licensing/re_salesperson/re_sales } \\
\text { _broker_faq.html\#18. }\end{array}$ \\
\hline North Dakota & & & $\begin{array}{l}\text { North Dakota Century Code 43-23-11- } \\
1.1 \text { (l) }\end{array}$ & $\begin{array}{l}\text { North Dakota licensee cannot pay compensation or } \\
\text { commission to any person who is not licensed; however } \\
\text { the Real Estate Commission does not interpret this as } \\
\text { precluding paying a rebate to a party to the transaction. }\end{array}$ \\
\hline Oklahoma & pre-2000 & & Oklahoma Code, Title 59 \ 858-312(21) & $\begin{array}{l}\text { Licensee cannot pay any part of a fee or commission to } \\
\text { any person not licensed. }\end{array}$ \\
\hline Oregon & pre-2000 & & Oregon Revised Statute $\int 696.290(1)$ & $\begin{array}{l}\text { Licensee cannot pay or rebate any part of the licensee's } \\
\text { commission to any person who is not a licensee. }\end{array}$ \\
\hline South Carolina & pre-2000 & 2006 & South Carolina Code $\int 40-57-145(11)$ & $\begin{array}{l}\text { Licensee may pay a fee to an unlicensed individual that is a } \\
\text { party in the real estate transaction. Our research did not } \\
\text { uncover solid evidence of enactment date, and there was } \\
\text { small possibility that the anti-rebate law was enacted in } \\
2004 \text { - } 2004 \text { Act No. } 218 \text {, Sections } 20,21 \text {. }\end{array}$ \\
\hline South Dakota & pre-2000 & 2005 & $\begin{array}{l}\text { South Dakota Real Estate Commission } \\
\text { Resolution 06-30-05-01 }\end{array}$ & $\begin{array}{l}1993 \text { Declaratory Ruling prohibiting rebates was rescinded } \\
\text { in } 2005 \text {. }\end{array}$ \\
\hline
\end{tabular}




\begin{tabular}{|c|c|c|c|c|}
\hline Tennessee & pre-2000 & & $\begin{array}{l}\text { Tennessee Code Annotated \$ 62-13- } \\
302\end{array}$ & $\begin{array}{l}\text { Licensee cannot give or pay cash rebates, cash gifts or cash } \\
\text { prizes as part of real estate transaction. the original anti- } \\
\text { rebate law was part of Tennessee Real Estate Commission } \\
\text { Rule } 1260-2-.33(2) \text {; the Commission was going to repeal } \\
\text { rule, then in } 2007 \text { legislature enacted law prohibiting } \\
\text { rebates. }\end{array}$ \\
\hline West Virginia & pre-2000 & 2005 & Legislative Rule - CSR \$174-1-11.11.1 & $\begin{array}{l}\text { As of } 2005 \text {, regulation was not enforced. In } 2006 \text {, } \\
\text { regulation changed to allow gifts and rebates to clients and } \\
\text { customers if terms are disclosed in writing. }\end{array}$ \\
\hline TOTAL & 16 & 7 & & \\
\hline
\end{tabular}


TABLE 1a: Summary Statistics, VAR and Panel Fixed Effects Models (1984-2012)

\begin{tabular}{|c|c|c|c|c|c|c|}
\hline Variable name \& description & Obs & Mean & Std. Dev. & $\begin{array}{c}25^{\text {th }} \\
\text { percentile }\end{array}$ & $\begin{array}{c}50^{\text {th }} \\
\text { percentile }\end{array}$ & $\begin{array}{c}75^{\text {th }} \\
\text { percentile }\end{array}$ \\
\hline broker (Number of NAR members; National Association of Realtors (NAR)) & 1,479 & 17,477 & 23,353 & 3,966 & 10,346 & 21,096 \\
\hline cbkr $=\%$ Change in [broker] & 1,422 & 1.50 & 8.26 & -3.88 & 0.57 & 6.31 \\
\hline cbkr $=\%$ Change in [broker/population] & 1,422 & 0.52 & 8.05 & -4.59 & -0.22 & 5.17 \\
\hline cbkr $=\%$ Change in [broker $/($ population*per capita income $)]$ & 1,422 & -3.61 & 7.54 & -8.61 & -4.81 & 0.78 \\
\hline popl (Number of population; Census Bureau) & 1,479 & $5,389,693$ & $6,003,661$ & $1,332,213$ & $3,668,976$ & $6,306,019$ \\
\hline pci (Per capita income in \$; Bureau of Economic Analysis) & 1,479 & 27,169 & 10,485 & 18,605 & 25,807 & 34,412 \\
\hline chpi (\% Change in House Price Index; FHFA) & 1,479 & 3.74 & 6.01 & 0.54 & 3.71 & 6.04 \\
\hline trans (Number of transactions in '000s; National Association of Realtors) & 1,171 & 94.06 & 101.34 & 26.1 & 62.6 & 116.8 \\
\hline ctrans $(\%$ change in transactions $)$ & 1,119 & 2.48 & 11.17 & -3.59 & 2.75 & 8.91 \\
\hline
\end{tabular}

TABLE 1b: Summary Statistics, Law Change Dummy Variables, 2000-2012

\begin{tabular}{|c|c|c|c|}
\hline Variable name $\&$ description & Obs & Mean & $\begin{array}{l}\text { Std. } \\
\text { Dev. }\end{array}$ \\
\hline Alaw1 (Law change allowing transaction brokers ) - 12 states changed & 663 & 0.113 & 0.316 \\
\hline Alaw2 (Rescission of anti-rebate) - 7 states changed & 663 & 0.061 & 0.238 \\
\hline $\begin{array}{l}\text { Alaw3 (All law change facilitating unbundling: } \Delta \mathbf{L a w} \mathbf{1} \text { and } \Delta \mathbf{L a w} \mathbf{2} \text { combined) } \\
\text { - } 18 \text { states }\end{array}$ & 663 & 0.167 & 0.373 \\
\hline
\end{tabular}

Notes: Law change dummies are based on data presented in Appendix Tables A1-A3. All law change variables equal 0 before a change, 1 in the years following a change. Alaw 1 includes change to waivable minimum service (9 states) and to allow non-agency relationships (in 3 states). $\Delta$ law 2 includes rescission of anti-rebate laws in 7 states. Alaw3 includes all changes promoting unbundling (18 states). In 2009 , Montana passed rescission and also allowed waivable minimum services. It is counted only once in $\Delta$ law3. Note that pre-trend adjustments are the same for both changes.

We had complete broker data on 29 years in 51 states, or 1,428 changes from 1984-2012. We deleted 6 extreme outliers resulting in 1,422 observations.

NAR transactions were available from 1989 except for two years in New Hampshire, resulting in 1,171 observations. 
TABLE 2: Basic Brokerage Cost Model without Regulatory Intervention: Panel VAR (1984-2012)

\begin{tabular}{|c|c|c|c|c|c|c|c|c|c|}
\hline & \multicolumn{3}{|c|}{ Change in [broker] } & \multicolumn{3}{|c|}{ Change in [broker/popl] } & \multicolumn{3}{|c|}{ Change in [broker/(popl*pci)] } \\
\hline & $\begin{array}{c}\Delta \text { broker } \\
\text { (1) }\end{array}$ & $\begin{array}{c}\Delta \text { hpi } \\
(2)\end{array}$ & $\begin{array}{c}\Delta \text { transactions } \\
\text { (3) }\end{array}$ & $\begin{array}{c}\Delta \text { broker } \\
\text { (4) }\end{array}$ & $\begin{array}{c}\Delta \text { hpi } \\
(5)\end{array}$ & $\begin{array}{c}\Delta \text { transactions } \\
(6)\end{array}$ & $\begin{array}{c}\Delta \text { broker } \\
(7)\end{array}$ & $\begin{array}{c}\Delta \text { hpi } \\
(8)\end{array}$ & $\begin{array}{c}\Delta \text { transactions } \\
(9)\end{array}$ \\
\hline$\Delta$ broker_lag1 & $\begin{array}{c}0.233^{* * *} \\
(4.45)\end{array}$ & $\begin{array}{c}0.123^{* * *} \\
(6.11)\end{array}$ & $\begin{array}{l}-0.051 \\
(-0.83)\end{array}$ & $\begin{array}{c}0.241 * * * \\
(4.60)\end{array}$ & $\begin{array}{c}0.115^{* * *} \\
(5.79)\end{array}$ & $\begin{array}{l}-0.091 \\
(-1.50)\end{array}$ & $\begin{array}{c}0.220 * * * \\
(4.59)\end{array}$ & $\begin{array}{c}0.083^{* * *} \\
(4.55)\end{array}$ & $\begin{array}{c}-0.273 * * * \\
(-4.81)\end{array}$ \\
\hline$\Delta$ broker_lag2 & $\begin{array}{c}0.193^{* * *} \\
(4.83)\end{array}$ & $\begin{array}{c}0.058^{* * * *} \\
(3.21)\end{array}$ & $\begin{array}{l}-0.046 \\
(-0.75)\end{array}$ & $\begin{array}{c}0.198^{* * *} \\
(4.99)\end{array}$ & $\begin{array}{c}0.055^{* * *} \\
(3.17)\end{array}$ & $\begin{array}{l}-0.071 \\
(-1.16)\end{array}$ & $\begin{array}{c}0.156^{* * *} \\
(3.50)\end{array}$ & $\begin{array}{c}0.072^{* * *} \\
(3.99)\end{array}$ & $\begin{array}{c}-0.112^{*} \\
(-1.91)\end{array}$ \\
\hline$\Delta$ hpi_lag1 & $\begin{array}{c}0.227 * * * \\
(2.69)\end{array}$ & $\begin{array}{c}0.581 * * * \\
(10.77)\end{array}$ & $\begin{array}{c}-0.259 * \\
(-1.82)\end{array}$ & $\begin{array}{c}0.205^{* *} \\
(2.40)\end{array}$ & $\begin{array}{c}0.591 * * * \\
(10.93)\end{array}$ & $\begin{array}{l}-0.222 \\
(-1.57)\end{array}$ & $\begin{array}{c}0.262^{* * * *} \\
(3.21)\end{array}$ & $\begin{array}{c}0.634 * * * \\
(11.54)\end{array}$ & $\begin{array}{l}-0.161 \\
(-1.18)\end{array}$ \\
\hline$\Delta$ hpi_lag2 & $\begin{array}{l}-0.024 \\
(-0.35)\end{array}$ & $\begin{array}{l}0.049 \\
(1.15)\end{array}$ & $\begin{array}{c}0.423^{* * *} \\
(3.04)\end{array}$ & $\begin{array}{l}-0.023 \\
(-0.32)\end{array}$ & $\begin{array}{l}0.053 \\
(1.25)\end{array}$ & $\begin{array}{c}0.428^{* * * *} \\
(3.08)\end{array}$ & $\begin{array}{l}-0.040 \\
(-0.57)\end{array}$ & $\begin{array}{l}0.053 \\
(1.22)\end{array}$ & $\begin{array}{c}0.433 * * * \\
(3.14)\end{array}$ \\
\hline$\Delta$ transactions_lag1 & $\begin{array}{c}0.267 * * * \\
(11.84)\end{array}$ & $\begin{array}{c}0.086 * * * \\
(6.91)\end{array}$ & $\begin{array}{c}0.449 * * * \\
(10.11)\end{array}$ & $\begin{array}{c}0.257 * * * \\
(11.68)\end{array}$ & $\begin{array}{c}0.088^{* * *} \\
(6.97)\end{array}$ & $\begin{array}{c}0.451 * * * \\
(10.11)\end{array}$ & $\begin{array}{c}0.214^{* * *} \\
(10.25)\end{array}$ & $\begin{array}{c}0.094 * * * \\
(7.26)\end{array}$ & $\begin{array}{c}0.464^{* * *} \\
(10.46)\end{array}$ \\
\hline$\Delta$ transactions_lag2 & $\begin{array}{l}-0.001 \\
(-0.07)\end{array}$ & $\begin{array}{c}0.087 * * * \\
(7.98)\end{array}$ & $\begin{array}{l}-0.035 \\
(-0.85)\end{array}$ & $\begin{array}{l}-0.007 \\
(-0.35)\end{array}$ & $\begin{array}{c}0.090 * * * \\
(8.15)\end{array}$ & $\begin{array}{l}-0.026 \\
(-0.63)\end{array}$ & $\begin{array}{c}-0.075^{* * *} \\
(-3.87)\end{array}$ & $\begin{array}{c}0.095^{* * *} \\
(8.71)\end{array}$ & $\begin{array}{l}-0.001 \\
(-0.02)\end{array}$ \\
\hline
\end{tabular}

Note: ***, **, * represent statistical significance at the $1 \%, 5 \%$ and $10 \%$ level, respectively. Robust standard errors are used in computing t-statistics. The variables are de-meaned prior to VAR specification to control for the state-level unobserved heterogeneity and models are run with GMM procedure. 
TABLE 3: Basic Brokerage Cost Model without Regulatory Intervention: State Fixed Effects Framework (1984-2012)

\begin{tabular}{|c|c|c|c|c|c|c|c|c|c|}
\hline & \multicolumn{3}{|c|}{ Change in [broker] } & \multicolumn{3}{|c|}{ Change in [broker/popl] } & \multicolumn{3}{|c|}{ Change in [broker/(popl*pci)] } \\
\hline & (1) & $(2)$ & (3) & (4) & (5) & $(6)$ & $(7)$ & (8) & $(9)$ \\
\hline \multirow[t]{2}{*}{$\Delta$ broker_lag1 } & $0.343^{* * *}$ & $0.144^{* *}$ & -0.0161 & $0.337 * * *$ & $0.119 * *$ & -0.042 & $0.256^{* * *}$ & 0.066 & -0.049 \\
\hline & $(5.62)$ & $(2.36)$ & $(-0.29)$ & $(5.61)$ & $(1.98)$ & $(-0.78)$ & $(5.37)$ & $(1.15)$ & $(-0.98)$ \\
\hline \multirow[t]{2}{*}{$\Delta$ broker_lag2 } & $0.0792 * *$ & $0.100^{* * *}$ & $0.078^{* *}$ & $0.083^{* *}$ & $0.094 * * *$ & $0.063^{*}$ & 0.041 & 0.040 & 0.008 \\
\hline & $(2.23)$ & $(3.03)$ & $(2.06)$ & $(2.37)$ & $(2.84)$ & $(1.66)$ & $(1.17)$ & $(1.00)$ & $(0.20)$ \\
\hline \multirow[t]{2}{*}{$\Delta$ hpi_lag1 } & $0.342^{* * *}$ & $0.240^{*}$ & $0.211 * *$ & $0.321 * * *$ & $0.216^{*}$ & $0.180^{* *} *$ & $0.328^{* * *}$ & $0.176^{*}$ & $0.124^{*}$ \\
\hline & $(2.94)$ & $(1.85)$ & $(2.33)$ & $(2.90)$ & $(1.76)$ & $(2.10)$ & $(3.46)$ & $(1.80)$ & $(1.89)$ \\
\hline \multirow[t]{2}{*}{$\Delta$ hpi_lag2 } & $-0.287 * * *$ & $-0.167 *$ & 0.0305 & $-0.279 * * *$ & -0.155 & 0.0434 & $-0.216^{* * *}$ & -0.081 & $0.102^{*}$ \\
\hline & $(-3.03)$ & $(-1.66)$ & $(0.37)$ & $(-3.04)$ & $(-1.62)$ & $(0.54)$ & $(-2.79)$ & $(-1.10)$ & $(1.82)$ \\
\hline \multirow[t]{2}{*}{$\Delta$ transactions_lag1 } & & & $0.146^{* * *}$ & & & $0.140^{* * *}$ & & & $0.123^{* * *}$ \\
\hline & & & $(6.95)$ & & & $(6.95)$ & & & $(5.74)$ \\
\hline \multirow[t]{2}{*}{$\Delta$ transactions_lag2 } & & & 0.026 & & & 0.024 & & & $0.028^{*}$ \\
\hline & & & $(1.27)$ & & & $(1.33)$ & & & $(1.81)$ \\
\hline \multirow{2}{*}{ Intercept } & $0.359 *$ & 1.369 & -1.234 & -0.170 & 1.213 & $-2.755^{* *}$ & $-3.241 * * *$ & $-2.622 * *$ & $-7.994 * * *$ \\
\hline & $(1.93)$ & $(1.16)$ & $(-1.15)$ & $(-0.76)$ & $(1.08)$ & $(-2.49)$ & $(-8.34)$ & $(-2.54)$ & $(-6.99)$ \\
\hline $\begin{array}{l}\text { Model } \\
\text { Specification }\end{array}$ & State FE & $\begin{array}{c}\text { State \& } \\
\text { Time FE }\end{array}$ & $\begin{array}{c}\text { State \& } \\
\text { Time FE }\end{array}$ & State FE & $\begin{array}{c}\text { State \& } \\
\text { Time FE }\end{array}$ & $\begin{array}{c}\text { State \& Time } \\
\text { FE }\end{array}$ & State FE & $\begin{array}{c}\text { State \& } \\
\text { Time FE }\end{array}$ & $\begin{array}{c}\text { State \& Time } \\
\text { FE }\end{array}$ \\
\hline R-sq & 0.259 & 0.509 & 0.601 & 0.248 & 0.514 & 0.607 & 0.165 & 0.490 & 0.571 \\
\hline $\mathrm{N}$ & 1313 & 1313 & 1056 & 1313 & 1313 & 1056 & 1318 & 1318 & 1059 \\
\hline
\end{tabular}

Note: ***, **, * represent statistical significance at the 1\%,5\% and 10\% level, respectively. Robust standard errors are used in computing t-statistics. 
TABLE 4a: Brokerage Cost Model with Regulatory Intervention: State Fixed Effects Framework (2000-2012)

(Dependent variable: Change in [broker])

\begin{tabular}{|c|c|c|c|c|c|c|c|c|c|}
\hline & $(1)$ & $(2)$ & (3) & $(4)$ & $(5)$ & $(6)$ & $(7)$ & $(8)$ & $(9)$ \\
\hline$\Delta$ broker_lag1 & $\begin{array}{c}0.383 * * * \\
(8.33)\end{array}$ & $\begin{array}{c}0.378^{* * *} \\
(8.37)\end{array}$ & $\begin{array}{c}0.383^{* * *} \\
(8.40)\end{array}$ & $\begin{array}{l}0.318^{* * *} \\
(4.82)\end{array}$ & $\begin{array}{c}0.289 * * * \\
(5.63)\end{array}$ & $\begin{array}{c}0.312^{* * *} \\
(5.04)\end{array}$ & $\begin{array}{l}0.314^{* * *} \\
(4.72)\end{array}$ & $\begin{array}{c}0.289 * * * \\
(5.68)\end{array}$ & $\begin{array}{c}0.309 * * * \\
(4.85)\end{array}$ \\
\hline$\Delta$ hpi_lag1 & $\begin{array}{c}0.241 * * * \\
(5.16)\end{array}$ & $\begin{array}{c}0.261^{* * *} \\
(5.59)\end{array}$ & $\begin{array}{c}0.232^{* * *} \\
(4.96)\end{array}$ & $\begin{array}{l}0.065 \\
(1.11)\end{array}$ & $\begin{array}{c}0.093^{*} \\
(1.83)\end{array}$ & $\begin{array}{l}0.061 \\
(1.05)\end{array}$ & $\begin{array}{l}0.066 \\
(1.13)\end{array}$ & $\begin{array}{c}0.092^{*} \\
(1.82)\end{array}$ & $\begin{array}{l}0.062 \\
(1.06)\end{array}$ \\
\hline$\Delta$ transactions_lag1 & $\begin{array}{l}0.179 * * * \\
(6.68)\end{array}$ & $\begin{array}{c}0.182^{* * * *} \\
(6.87)\end{array}$ & $\begin{array}{l}0.176^{* * *} \\
(6.67)\end{array}$ & $\begin{array}{l}0.116^{* * *} \\
(6.11)\end{array}$ & $\begin{array}{l}0.123^{* * *} \\
\quad(6.65)\end{array}$ & $\begin{array}{l}0.116^{* * *} \\
(6.15)\end{array}$ & $\begin{array}{l}0.126 * * * \\
(5.84)\end{array}$ & $\begin{array}{l}0.122 * * * \\
(6.56)\end{array}$ & $\begin{array}{l}0.125^{* * *} \\
(5.74)\end{array}$ \\
\hline $\begin{array}{l}\text { Law change allowing } \\
\text { transaction brokers ( } \Delta \text { law } 1)\end{array}$ & $\begin{array}{c}-2.487 * * * \\
(-3.78)\end{array}$ & 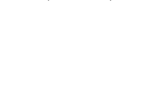 & & $\begin{array}{l}0.111 \\
(0.12)\end{array}$ & $-x^{-2}$ & & $\begin{array}{l}-0.052 \\
(-0.05)\end{array}$ & & \\
\hline $\begin{array}{l}\text { Rescission of Anti-rebate } \\
(\Delta \Delta \text { law } 2)\end{array}$ & & $\begin{array}{c}-2.695 * * * \\
(-2.95)\end{array}$ & & & $\begin{array}{c}-4.781 * * \\
(-2.48)\end{array}$ & & & $\begin{array}{c}-4.716^{* *} \\
(-2.64)\end{array}$ & \\
\hline $\begin{array}{l}\text { Law change allowing } \\
\text { unbundling }(\Delta \text { law } 3)\end{array}$ & & & $\begin{array}{c}-2.686 * * * \\
(-4.72)\end{array}$ & & & $\begin{array}{l}-2.038^{*} \\
(-1.74)\end{array}$ & & & $\begin{array}{l}-2.186 * \\
(-1.86)\end{array}$ \\
\hline$\Delta$ transactions_lag1* $\Delta$ law1 & & & & & & & $\begin{array}{l}-0.041 \\
(-1.01)\end{array}$ & & \\
\hline$\Delta$ transactions_lag1* $\Delta$ law2 & & & & & & & & $\begin{array}{l}0.016 \\
(0.24)\end{array}$ & \\
\hline$\Delta$ transactions_lag $1 * \Delta$ law3 & & & & & & & & & $\begin{array}{l}-0.035 \\
(-0.98)\end{array}$ \\
\hline global financial crisis (GFC) & $-5.715^{* * *}$ & $-5.855^{* * *}$ & $-5.574 * * *$ & $-2.477 * * *$ & $-2.630 * * *$ & $-2.498 * * *$ & $-2.476 * * *$ & $-2.618 * * *$ & $-2.517 * * *$ \\
\hline dummy $=1$ in 2007, 2008, 2009 & $(-12.34)$ & $(-12.14)$ & $(-12.10)$ & $(-5.67)$ & $(-5.87)$ & $(-5.92)$ & $(-5.96)$ & $(-5.81)$ & $(-6.17)$ \\
\hline Intercept & $\begin{array}{c}1.677 * * * \\
(8.99) \\
\end{array}$ & $\begin{array}{c}1.523^{* * *} \\
(8.43) \\
\end{array}$ & $\begin{array}{c}1.845^{* * *} \\
(9.21)\end{array}$ & $\begin{array}{l}-2.375^{* * *} \\
(-6.58) \\
\end{array}$ & $\begin{array}{c}-1.789 * * * \\
(-4.54) \\
\end{array}$ & $\begin{array}{c}-1.706 * * * \\
(-3.83) \\
\end{array}$ & $\begin{array}{l}-2.348^{* * *} \\
(-6.48)\end{array}$ & $\begin{array}{c}-1.797 * * * \\
(-4.69) \\
\end{array}$ & $\begin{array}{c}-1.667 * * * \\
(-3.74) \\
\end{array}$ \\
\hline $\begin{array}{l}\text { Less pre-existing state-specific } \\
\text { trend }\end{array}$ & no & no & no & yes & yes & yes & yes & yes & yes \\
\hline Model Specification & State FE & State FE & State FE & $\begin{array}{l}\text { State \& } \\
\text { Time FE }\end{array}$ & $\begin{array}{l}\text { State \& } \\
\text { Time FE }\end{array}$ & $\begin{array}{l}\text { State \& } \\
\text { Time FE }\end{array}$ & $\begin{array}{l}\text { State \& } \\
\text { Time FE }\end{array}$ & $\begin{array}{c}\text { State \& } \\
\text { Time FE }\end{array}$ & $\begin{array}{l}\text { State \& } \\
\text { Time FE }\end{array}$ \\
\hline $\begin{array}{c}\text { R-sq } \\
\mathrm{N}\end{array}$ & $\begin{array}{c}0.705 \\
659\end{array}$ & $\begin{array}{c}0.703 \\
659 \\
\end{array}$ & $\begin{array}{c}0.708 \\
659\end{array}$ & $\begin{array}{c}0.807 \\
659 \\
\end{array}$ & $\begin{array}{c}0.816 \\
659\end{array}$ & $\begin{array}{c}0.811 \\
659\end{array}$ & $\begin{array}{c}0.808 \\
659\end{array}$ & $\begin{array}{c}0.816 \\
659\end{array}$ & $\begin{array}{c}0.811 \\
659\end{array}$ \\
\hline
\end{tabular}

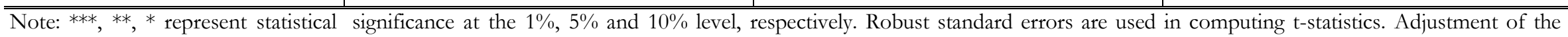

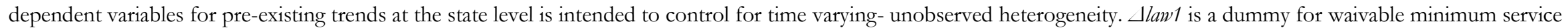
and non-agency. Slaw2 is rescission of anti-rebate laws. $\Delta$ law 3 is all changes promoting unbundling combined. 
TABLE 4b: Brokerage Cost Model with Regulatory Intervention: State Fixed Effects Framework (2000-2012)

(Dependent variable: Change in [broker/population])

\begin{tabular}{|c|c|c|c|c|c|c|c|c|c|}
\hline & (1) & $(2)$ & (3) & (4) & (5) & (6) & $(7)$ & (8) & $(9)$ \\
\hline$\Delta$ broker_lag1 & $\begin{array}{l}0.351 * * * \\
(8.27)\end{array}$ & $\begin{array}{c}0.346^{* * *} \\
(8.28)\end{array}$ & $\begin{array}{l}0.351 * * * \\
(8.31)\end{array}$ & $\begin{array}{c}0.275^{* * *} \\
(4.31)\end{array}$ & $\begin{array}{c}0.246^{* * *} \\
(4.98)\end{array}$ & $\begin{array}{c}0.270^{* * *} \\
(4.49)\end{array}$ & $\begin{array}{c}0.272 * * * \\
(4.23)\end{array}$ & $\begin{array}{c}0.246^{* * *} \\
(5.00)\end{array}$ & $\begin{array}{c}0.267 * * * \\
(4.34)\end{array}$ \\
\hline$\Delta$ hpi_lag1 & $\begin{array}{c}0.255^{* * *} \\
(5.85)\end{array}$ & $\begin{array}{c}0.275^{* * *} \\
\quad(6.36)\end{array}$ & $\begin{array}{c}0.247 * * * \\
(5.63)\end{array}$ & $\begin{array}{l}0.081 \\
(1.51)\end{array}$ & $\begin{array}{c}0.107^{* *} \\
(2.32)\end{array}$ & $\begin{array}{l}0.074 \\
(1.39)\end{array}$ & $\begin{array}{l}0.081 \\
(1.52)\end{array}$ & $\begin{array}{c}0.107 * * \\
(2.31)\end{array}$ & $\begin{array}{l}0.075 \\
(1.41)\end{array}$ \\
\hline$\Delta$ transactions_lag1 & $\begin{array}{l}0.185^{* * *} \\
(7.18)\end{array}$ & $\begin{array}{c}0.187^{* * * *} \\
(7.38)\end{array}$ & $\begin{array}{l}0.181 * * * \\
(7.17)\end{array}$ & $\begin{array}{l}0.123^{* * *} \\
(6.42)\end{array}$ & $\begin{array}{l}0.129 * * * \\
(6.97)\end{array}$ & $\begin{array}{l}0.122^{* * *} \\
(6.39)\end{array}$ & $\begin{array}{l}0.131 * * * \\
(5.80)\end{array}$ & $\begin{array}{c}0.130^{* * *} \\
(7.00)\end{array}$ & $\begin{array}{c}0.132 * * * \\
\quad(5.87)\end{array}$ \\
\hline $\begin{array}{l}\text { Law change allowing } \\
\text { transaction brokers ( } \Delta \text { law } 1)\end{array}$ & $\begin{array}{c}-2.361 * * * \\
(-3.95)\end{array}$ & & & $\begin{array}{l}0.282 \\
(0.35)\end{array}$ & & & $\begin{array}{l}0.140 \\
(0.17)\end{array}$ & & \\
\hline $\begin{array}{l}\text { Rescission of Anti-rebate } \\
(\triangle \text { law } 2)\end{array}$ & & $\begin{array}{c}-2.738 * * * \\
(-3.04)\end{array}$ & & & $\begin{array}{c}-4.989 * * \\
(-2.62)\end{array}$ & & & $\begin{array}{c}-5.002 * * * \\
(-2.87)\end{array}$ & \\
\hline $\begin{array}{l}\text { Law change allowing } \\
\text { unbundling (Alaw3) }\end{array}$ & & & $\begin{array}{c}-2.619 * * * \\
(-4.91)\end{array}$ & & & $\begin{array}{l}-2.009 * \\
(-1.78)\end{array}$ & & & $\begin{array}{l}-2.153^{*} \\
(-1.94)\end{array}$ \\
\hline$\Delta$ transactions_lag1* $\Delta$ law1 & & & & & & & $\begin{array}{l}-0.035 \\
(-1.08)\end{array}$ & & \\
\hline$\Delta$ transactions_lag1* $\Delta$ law2 & & & & & & & & $\begin{array}{l}-0.003 \\
(-0.04)\end{array}$ & \\
\hline$\Delta$ transactions_lag1* $\Delta$ law3 & & & & & & & & & $\begin{array}{l}-0.034 \\
(-1.14)\end{array}$ \\
\hline global financial crisis (GFC) & $-5.720 * * *$ & $-5.846 * * *$ & $-5.577 * * *$ & $-2.389 * * *$ & $-2.543 * * *$ & $-2.408 * * *$ & $-2.389 * * *$ & $-2.546 * * *$ & $-2.427 * * *$ \\
\hline dummy $=1$ in 2007, 2008, 2009 & $(-12.55)$ & $(-12.55)$ & $(-12.30)$ & $(-6.22)$ & $(-6.40)$ & $(-6.50)$ & $(-6.32)$ & $(-6.44)$ & $(-6.61)$ \\
\hline Intercept & $\begin{array}{c}1.070^{* * *} \\
(5.29) \\
\end{array}$ & $\begin{array}{c}0.931 * * * \\
(4.64)\end{array}$ & $\begin{array}{c}1.241 * * * \\
(5.79) \\
\end{array}$ & $\begin{array}{c}-3.169 * * * \\
(-10.19) \\
\end{array}$ & $\begin{array}{c}-2.549 * * * \\
(-6.55) \\
\end{array}$ & $\begin{array}{c}-2.475^{* * *} \\
(-5.66) \\
\end{array}$ & $\begin{array}{c}-3.145^{* * *} \\
(-10.06) \\
\end{array}$ & $\begin{array}{c}-2.547 * * * \\
(-6.84) \\
\end{array}$ & $\begin{array}{c}-2.437 * * * \\
(-5.62) \\
\end{array}$ \\
\hline $\begin{array}{l}\text { Less pre-existing state-specific } \\
\text { trend }\end{array}$ & no & no & no & yes & yes & yes & yes & yes & yes \\
\hline Model Specification & State FE & State FE & State FE & $\begin{array}{l}\text { State \& } \\
\text { Time FE }\end{array}$ & $\begin{array}{l}\text { State \& } \\
\text { Time FE }\end{array}$ & $\begin{array}{l}\text { State \& } \\
\text { Time FE }\end{array}$ & $\begin{array}{l}\text { State \& } \\
\text { Time FE }\end{array}$ & $\begin{array}{l}\text { State \& } \\
\text { Time FE }\end{array}$ & $\begin{array}{l}\text { State \& } \\
\text { Time FE }\end{array}$ \\
\hline $\begin{array}{c}\text { R-sq } \\
\mathrm{N}\end{array}$ & $\begin{array}{c}0.684 \\
659\end{array}$ & $\begin{array}{c}0.683 \\
659 \\
\end{array}$ & $\begin{array}{c}0.687 \\
659 \\
\end{array}$ & $\begin{array}{c}0.793 \\
659\end{array}$ & $\begin{array}{c}0.802 \\
659\end{array}$ & $\begin{array}{c}0.796 \\
659\end{array}$ & $\begin{array}{c}0.793 \\
659\end{array}$ & $\begin{array}{c}0.802 \\
659\end{array}$ & $\begin{array}{c}0.797 \\
659\end{array}$ \\
\hline
\end{tabular}

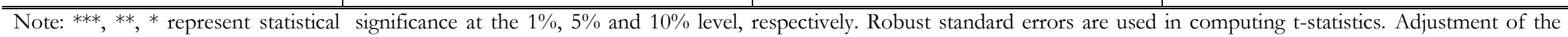

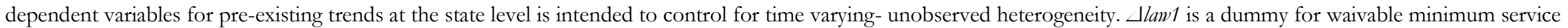
and non-agency. $\Delta$ law 2 is rescission of anti-rebate laws. $\Delta$ law 3 is all changes promoting unbundling combined. 
TABLE 4c: Brokerage Cost Model with Regulatory Intervention: State Fixed Effects Framework (2000-2012) (Dependent variable: Change in [broker/(population*per capita income)])

\begin{tabular}{|c|c|c|c|c|c|c|c|c|c|}
\hline & $(1)$ & $(2)$ & $(3)$ & $(4)$ & $(5)$ & $(6)$ & $(7)$ & $(8)$ & $(9)$ \\
\hline$\Delta$ broker_lag1 & $\begin{array}{c}0.128^{* * *} \\
(2.81)\end{array}$ & $\begin{array}{c}0.123^{* * *} \\
(2.83)\end{array}$ & $\begin{array}{c}0.130 * * * \\
(2.86)\end{array}$ & $\begin{array}{c}0.142^{*} \\
(1.95)\end{array}$ & $\begin{array}{c}0.107^{*} \\
(1.92)\end{array}$ & $\begin{array}{c}0.137 * * \\
(2.02)\end{array}$ & $\begin{array}{c}0.142^{*} \\
(1.95)\end{array}$ & $\begin{array}{c}0.107 * \\
(1.93)\end{array}$ & $\begin{array}{c}0.137 * * \\
(2.03)\end{array}$ \\
\hline$\Delta$ hpi_lag1 & $\begin{array}{l}0.335^{* * *} \\
\quad(8.40)\end{array}$ & $\begin{array}{l}0.353 * * * \\
(9.38)\end{array}$ & $\begin{array}{l}0.322^{* * *} \\
\quad(8.16)\end{array}$ & $\begin{array}{c}0.162^{* * *} \\
(3.55)\end{array}$ & $\begin{array}{c}0.180^{* * *} \\
(4.56)\end{array}$ & $\begin{array}{c}0.151 * * * \\
(3.36)\end{array}$ & $\begin{array}{c}0.162^{* * *} \\
(3.53)\end{array}$ & $\begin{array}{c}0.180^{* * *} \\
(4.54)\end{array}$ & $\begin{array}{l}0.151 * * * \\
(3.35)\end{array}$ \\
\hline$\Delta$ transactions_lag1 & $\begin{array}{l}0.211^{* * *} \\
(7.28)\end{array}$ & $\begin{array}{l}0.213^{* * *} * \\
(7.44)\end{array}$ & $\begin{array}{l}0.206^{* * *} \\
(7.27)\end{array}$ & $\begin{array}{c}0.128^{* * *} \\
(5.09)\end{array}$ & $\begin{array}{l}0.133^{* * *} \\
\quad(5.44)\end{array}$ & $\begin{array}{l}0.126^{* * *} \\
(5.13)\end{array}$ & $\begin{array}{l}0.126^{* * *} \\
\quad(4.31)\end{array}$ & $\begin{array}{c}0.133^{* * *} \\
(5.39)\end{array}$ & $\begin{array}{l}0.122 * * * \\
(4.27)\end{array}$ \\
\hline $\begin{array}{l}\text { Law change allowing } \\
\text { transaction brokers }(\Delta \text { law } 1)\end{array}$ & $\begin{array}{c}-2.538 * * * \\
(-3.84)\end{array}$ & & & $\begin{array}{l}0.642 \\
(0.87)\end{array}$ & & & $\begin{array}{l}0.683 \\
(0.94)\end{array}$ & & \\
\hline $\begin{array}{l}\text { Rescission of Anti-rebate } \\
(\Delta \Delta \text { law } 2)\end{array}$ & & $\begin{array}{c}-3.486 * * * \\
(-3.72)\end{array}$ & & & $\begin{array}{c}-6.008 * * * \\
(-2.87)\end{array}$ & & & $\begin{array}{c}-5.939 * * * \\
(-3.04)\end{array}$ & \\
\hline $\begin{array}{l}\text { Law change allowing } \\
\text { unbundling }(\Delta \text { law } 3)\end{array}$ & & & $\begin{array}{c}-3.061 * * * \\
(-5.16)\end{array}$ & & & $\begin{array}{l}-2.228^{*} \\
(-1.81)\end{array}$ & & & $\begin{array}{l}-2.166^{*} \\
(-1.78)\end{array}$ \\
\hline$\Delta$ transactions_lag1* $\Delta$ law1 & & & & & & & $\begin{array}{l}0.009 \\
(0.29)\end{array}$ & & \\
\hline $\boldsymbol{\Delta}$ transactions_lag $1 * \boldsymbol{\Delta} \Delta$ law 2 & & & & & & & & $\begin{array}{l}0.017 \\
(0.20)\end{array}$ & \\
\hline$\Delta$ transactions_lag1 $* \Delta$ law3 & & & & & & & & & $\begin{array}{l}0.015 \\
(0.48)\end{array}$ \\
\hline $\begin{array}{l}\text { global financial crisis (GFC) } \\
\text { dummy }=1 \text { in } 2007,2008,2009\end{array}$ & $\begin{array}{c}-3.357 * * * \\
(-6.89)\end{array}$ & $\begin{array}{c}-3.478 * * * \\
(-7.17)\end{array}$ & $\begin{array}{c}-3.163 * * * \\
(-6.46)\end{array}$ & $\begin{array}{c}-0.916^{* *} \\
(-2.14)\end{array}$ & $\begin{array}{l}-1.100 * * \\
(-2.68)\end{array}$ & $\begin{array}{c}-0.933 * * \\
(-2.27)\end{array}$ & $\begin{array}{c}-0.916^{* *} \\
(-2.13)\end{array}$ & $\begin{array}{c}-1.089 * * \\
(-2.57)\end{array}$ & $\begin{array}{c}-0.925^{* *} \\
(-2.25)\end{array}$ \\
\hline Intercept & $\begin{array}{c}-2.609 * * * \\
(-8.49)\end{array}$ & $\begin{array}{c}-2.738 * * * \\
(-9.48) \\
\end{array}$ & $\begin{array}{c}-2.372 * * * \\
(-7.40) \\
\end{array}$ & $\begin{array}{c}-6.168 * * * \\
(-18.03) \\
\end{array}$ & $\begin{array}{c}-5.476 * * * \\
(-13.07) \\
\end{array}$ & $\begin{array}{c}-5.341 * * * \\
(-9.21) \\
\end{array}$ & $\begin{array}{c}-6.174 * * * \\
(-18.08) \\
\end{array}$ & $\begin{array}{c}-5.485^{* * *} \\
(-13.41) \\
\end{array}$ & $\begin{array}{c}-5.358^{* * *} \\
(-9.34) \\
\end{array}$ \\
\hline $\begin{array}{l}\text { Less pre-existing state-specific } \\
\text { trend }\end{array}$ & no & no & no & yes & yes & yes & yes & yes & yes \\
\hline Model Specification & State FE & State FE & State FE & $\begin{array}{l}\text { State \& } \\
\text { Time FE }\end{array}$ & $\begin{array}{l}\text { State } \& \\
\text { Time FE }\end{array}$ & $\begin{array}{l}\text { State } \& \\
\text { Time FE }\end{array}$ & $\begin{array}{l}\text { State } \& \\
\text { Time FE }\end{array}$ & $\begin{array}{l}\text { State \& } \\
\text { Time FE }\end{array}$ & $\begin{array}{l}\text { State \& } \\
\text { Time FE }\end{array}$ \\
\hline $\begin{array}{c}\text { R-sq } \\
\mathrm{N}\end{array}$ & $\begin{array}{c}0.471 \\
660\end{array}$ & $\begin{array}{c}0.472 \\
660 \\
\end{array}$ & $\begin{array}{c}0.477 \\
660\end{array}$ & $\begin{array}{c}0.687 \\
660 \\
\end{array}$ & $\begin{array}{c}0.702 \\
660\end{array}$ & $\begin{array}{c}0.691 \\
660\end{array}$ & $\begin{array}{c}0.687 \\
660\end{array}$ & $\begin{array}{c}0.702 \\
660\end{array}$ & $\begin{array}{c}0.691 \\
660\end{array}$ \\
\hline
\end{tabular}

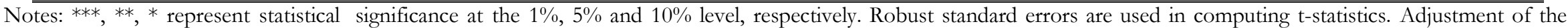

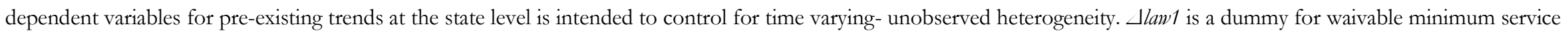
and non-agency. $\Delta$ law 2 is rescission of anti-rebate laws. $\Delta$ law 3 is all changes promoting unbundling combined. 
TABLE 5: Brokerage Cost Model with Regulatory Intervention: Dynamic Panel Framework (2000-2012)

\begin{tabular}{|c|c|c|c|c|c|c|c|c|c|}
\hline & \multicolumn{3}{|c|}{ Change in [broker] } & \multicolumn{3}{|c|}{ Change in [broker/population] } & \multicolumn{3}{|c|}{$\begin{array}{c}\text { Change in [broker/(population*per } \\
\text { capita income)] }\end{array}$} \\
\hline & (1) & (2) & (2) & (3) & (4) & (4) & $(5)$ & $(6)$ & $(6)$ \\
\hline$\Delta$ broker_lag1 & $\begin{array}{l}0.366^{* * *} \\
(6.16)\end{array}$ & $\begin{array}{l}0.309^{* * *} \\
(7.32)\end{array}$ & $\begin{array}{l}0.351 * * * \\
(6.78)\end{array}$ & $\begin{array}{l}0.321 * * * \\
(5.39)\end{array}$ & $\begin{array}{c}0.269 * * * \\
(6.55)\end{array}$ & $\begin{array}{l}0.310^{* * *} \\
(5.76)\end{array}$ & $\begin{array}{l}0.192^{* * *} \\
(2.95)\end{array}$ & $\begin{array}{c}0.130 * * * \\
(2.83)\end{array}$ & $\begin{array}{l}0.191^{* * *} \\
(3.24)\end{array}$ \\
\hline$\Delta$ hpi_lag1 & $\begin{array}{l}0.068 \\
(1.28)\end{array}$ & $\begin{array}{c}0.106^{* *} \\
(2.29)\end{array}$ & $\begin{array}{l}0.061 \\
(1.18)\end{array}$ & $\begin{array}{c}0.086^{*} \\
(1.77)\end{array}$ & $\begin{array}{c}0.121 * * * \\
(2.91)\end{array}$ & $\begin{array}{l}0.076 \\
(1.59)\end{array}$ & $\begin{array}{c}0.145^{* * *} \\
(3.37)\end{array}$ & $\begin{array}{c}0.171^{* * *} \\
(4.66)\end{array}$ & $\begin{array}{c}0.124^{* * *} \\
(3.08)\end{array}$ \\
\hline$\Delta$ transactions_lag1 & $\begin{array}{l}0.114 * * * \\
(5.56)\end{array}$ & $\begin{array}{c}0.121^{* * *} \\
(7.39)\end{array}$ & $\begin{array}{c}0.115^{* * *} \\
(5.57)\end{array}$ & $\begin{array}{l}0.112^{* * *} \\
(5.30)\end{array}$ & $\begin{array}{l}0.118^{* * *} \\
(6.92)\end{array}$ & $\begin{array}{c}0.113^{* * *} \\
(5.36)\end{array}$ & $\begin{array}{c}0.107 * * * \\
(3.97)\end{array}$ & $\begin{array}{l}0.125^{* * *} \\
(5.42)\end{array}$ & $\begin{array}{l}0.104 * * * \\
(3.87)\end{array}$ \\
\hline $\begin{array}{l}\text { Law change allowing } \\
\text { transaction brokers (_law } 1)\end{array}$ & $\begin{array}{l}0.420 \\
(0.66)\end{array}$ & & & $\begin{array}{l}0.430 \\
(0.73)\end{array}$ & & & $\begin{array}{c}1.500^{* *} \\
(2.48)\end{array}$ & & \\
\hline $\begin{array}{l}\text { Rescission of Anti-rebate } \\
(\Delta \Delta \text { law } 2)\end{array}$ & & $\begin{array}{c}-5.295^{* * *} \\
(-3.90)\end{array}$ & & & $\begin{array}{c}-5.338 * * * \\
(-4.05)\end{array}$ & & & $\begin{array}{c}-6.630 * * * \\
(-4.78)\end{array}$ & \\
\hline $\begin{array}{l}\text { All law change allowing } \\
\text { unbundling ( } \triangle \text { law } 3 \text { ) }\end{array}$ & & & $\begin{array}{l}-2.472^{* *} \\
(-2.36)\end{array}$ & & & $\begin{array}{c}-2.345^{* *} \\
(-2.39)\end{array}$ & & & $\begin{array}{c}-2.104 * * \\
(-1.98)\end{array}$ \\
\hline$\Delta$ transactions_lag $1 * \Delta \Delta$ law 1 & $\begin{array}{l}-0.029 \\
(-0.83)\end{array}$ & & & $\begin{array}{c}-0.0244 \\
(-0.82)\end{array}$ & & & $\begin{array}{l}0.022 \\
(0.68)\end{array}$ & & \\
\hline$\Delta$ transactions_lag $1 * \Delta \Delta$ law 2 & & $\begin{array}{l}-0.001 \\
(-0.02)\end{array}$ & & & $\begin{array}{l}-0.007 \\
(-0.10)\end{array}$ & & & $\begin{array}{l}-0.008 \\
(-0.09)\end{array}$ & \\
\hline$\Delta$ transactions_lag1* $\Delta$ law 3 & & & $\begin{array}{c}-0.029 \\
(-0.91)\end{array}$ & & & $\begin{array}{l}-0.024 \\
(-0.83)\end{array}$ & & & $\begin{array}{l}0.021 \\
(0.63)\end{array}$ \\
\hline $\begin{array}{l}\text { global financial crisis (GFC) } \\
\text { dummy }=1 \text { in } 2007,2008,2009\end{array}$ & $\begin{array}{c}-2.886^{* * *} \\
(-8.04)\end{array}$ & $\begin{array}{c}-2.907 * * * \\
(-6.94)\end{array}$ & $\begin{array}{c}-2.843 * * * \\
(-7.83)\end{array}$ & $\begin{array}{c}-2.888^{* * *} \\
(-8.50)\end{array}$ & $\begin{array}{l}-2.952^{* * *} \\
(-7.66)\end{array}$ & $\begin{array}{c}-2.857^{* * *} \\
(-8.23)\end{array}$ & $\begin{array}{c}-0.925^{* *} \\
(-2.33)\end{array}$ & $\begin{array}{c}-1.133 * * * \\
(-2.75)\end{array}$ & $\begin{array}{c}-0.895^{* *} \\
(-2.35)\end{array}$ \\
\hline $\begin{array}{l}\text { Less pre-existing state-specific } \\
\text { trend }\end{array}$ & yes & yes & yes & yes & yes & yes & yes & yes & yes \\
\hline $\begin{array}{l}\text { Arellano-Bond test for } \mathrm{AR}(1) \text { in } \\
\text { first differences: } p \text {-value }\end{array}$ & 0.000 & 0.000 & 0.000 & 0.000 & 0.000 & 0.000 & 0.000 & 0.000 & 0.000 \\
\hline $\begin{array}{l}\text { Arellano-Bond test for } \mathrm{AR}(2) \text { in } \\
\text { first differences: } p \text {-value }\end{array}$ & 0.106 & 0.115 & 0.105 & 0.269 & 0.330 & 0.255 & 0.000 & 0.000 & 0.001 \\
\hline $\begin{array}{l}\text { Hansen test of over-identifying } \\
\text { restrictions: } p \text {-value }\end{array}$ & 1.000 & 1.000 & 1.000 & 1.000 & 1.000 & 1.000 & 1.000 & 1.000 & 1.000 \\
\hline $\mathrm{N}$ & 659 & 659 & 659 & 659 & 659 & 659 & 659 & 659 & 659 \\
\hline
\end{tabular}

Note: ***, **, * represent statistical significance at the 1\%,5\% and $10 \%$ level, respectively. All models are estimated with one-step difference GMM with robust standard error specification to control for panel-specific auto-correlation and heteroscedasticity. $\Delta$ law 1 is a dummy for waivable minimum service and non-agency. $\Delta$ law 2 is rescission of anti-rebate laws. Alaw 3 is all changes promoting unbundling combined. 
TABLE 6: Brokerage Cost Model with Regulatory Intervention: MSA Fixed Effects Framework (2000-2012) (Dependent variable: Change in [broker]) comparable to Table $4 \mathrm{a}$ and 5

\begin{tabular}{|c|c|c|c|c|c|c|}
\hline & \multicolumn{3}{|c|}{ MSA Fixed Effect Models (Table 4a) } & \multicolumn{3}{|c|}{ MSA Dynamic Panel Models (Table 5) } \\
\hline & (1) & $(2)$ & (3) & $(4)$ & $(5)$ & (6) \\
\hline$\Delta$ broker_lag1 & $\begin{array}{c}0.549 * * * \\
(30.57)\end{array}$ & $\begin{array}{c}0.551^{* * * *} \\
(30.66)\end{array}$ & $\begin{array}{c}0.540^{* * *} \\
(30.38)\end{array}$ & $\begin{array}{l}0.590^{* * *} \\
(26.99)\end{array}$ & $\begin{array}{c}0.600^{* * *} \\
(25.13)\end{array}$ & $\begin{array}{c}0.578^{* * *} \\
(25.98)\end{array}$ \\
\hline$\Delta$ hpi_lag1 & $\begin{array}{c}0.096^{* * * *} \\
(3.88)\end{array}$ & $\begin{array}{c}0.103^{* * *} \\
(4.13)\end{array}$ & $\begin{array}{c}0.097 * * * \\
(3.99)\end{array}$ & $\begin{array}{c}0.081^{* * *} \\
(2.97)\end{array}$ & $\begin{array}{c}0.083^{* * *} \\
(2.89)\end{array}$ & $\begin{array}{c}0.081^{* * *} \\
(3.10)\end{array}$ \\
\hline$\Delta$ transactions_lag1 & $\begin{array}{c}0.016 * * * \\
(9.17)\end{array}$ & $\begin{array}{c}0.015^{* * *} \\
(8.20)\end{array}$ & $\begin{array}{c}0.014 * * * \\
(8.01)\end{array}$ & $\begin{array}{c}0.016^{* * *} \\
(7.86)\end{array}$ & $\begin{array}{c}0.016^{* * *} \\
(7.18)\end{array}$ & $\begin{array}{c}0.014 * * * \\
(7.10)\end{array}$ \\
\hline $\begin{array}{l}\text { Law change allowing } \\
\text { transaction brokers }(\Delta \text { law } 1)\end{array}$ & $\begin{array}{c}-2.989 * * * \\
(-9.33)\end{array}$ & & & $\begin{array}{c}-3.211 * * * \\
(-4.14)\end{array}$ & & \\
\hline $\begin{array}{l}\text { Rescission of Anti-rebate } \\
(\Delta \text { Alaw } 2)\end{array}$ & & $\begin{array}{c}-4.082^{* * *} \\
(-9.69)\end{array}$ & & & $\begin{array}{l}-9.329 * * * \\
(-4.89)\end{array}$ & \\
\hline $\begin{array}{l}\text { Law change allowing } \\
\text { unbundling }(\triangle \text { law } 3)\end{array}$ & & & $\begin{array}{c}-3.528^{* * *} \\
(-13.03)\end{array}$ & & & $\begin{array}{c}-5.613^{* * *} \\
(-6.92)\end{array}$ \\
\hline$\Delta$ transactions_lag1* $\Delta$ law 1 & & & & $\begin{array}{c}0.349^{* * *} \\
(5.54)\end{array}$ & & \\
\hline$\Delta$ transactions_lag1* $\Delta$ law 2 & & & & & $\begin{array}{c}1.229 * * * \\
(4.14)\end{array}$ & \\
\hline$\Delta$ transactions_lag1*_law3 & & & & & & $\begin{array}{c}0.357^{* * *} \\
(6.85)\end{array}$ \\
\hline $\begin{array}{l}\text { global financial crisis (GFC) } \\
\text { dummy }=1 \text { in } 2007,2008,2009\end{array}$ & $\begin{array}{c}-7.151 * * * \\
(-33.52)\end{array}$ & $\begin{array}{c}-7.219 * * * \\
(-34.07)\end{array}$ & $\begin{array}{c}-7.033 * * * \\
(-32.85)\end{array}$ & $\begin{array}{c}-6.832 * * * \\
(-32.89)\end{array}$ & $\begin{array}{c}-6.054 * * * \\
(-24.30)\end{array}$ & $\begin{array}{c}-6.273 * * * \\
(-29.79)\end{array}$ \\
\hline Intercept & $\begin{array}{c}2.481 * * * \\
(22.73)\end{array}$ & $\begin{array}{c}2.378^{* * *} \\
(22.43)\end{array}$ & $\begin{array}{c}2.738^{* * *} \\
(24.53)\end{array}$ & $\begin{array}{c}2.583^{* * *} \\
(20.96)\end{array}$ & $\begin{array}{c}2.694 * * * \\
(18.29)\end{array}$ & $\begin{array}{c}3.164 * * * \\
(21.85)\end{array}$ \\
\hline Model Specification & MSA FE & MSA FE & MSA FE & $\begin{array}{c}\text { Dynamic } \\
\text { Panel } \\
\end{array}$ & $\begin{array}{c}\text { Dynamic } \\
\text { Panel } \\
\end{array}$ & $\begin{array}{c}\text { Dynamic } \\
\text { Panel } \\
\end{array}$ \\
\hline $\begin{array}{c}\text { R-sq } \\
\mathrm{N}\end{array}$ & $\begin{array}{l}0.674 \\
4187 \\
\end{array}$ & $\begin{array}{r}0.674 \\
4187 \\
\end{array}$ & $\begin{array}{c}0.678 \\
4187 \\
\end{array}$ & 3805 & 3805 & 3805 \\
\hline
\end{tabular}

Note: $* * *, * *, *$ represent statistical significance at the $1 \%, 5 \%$ and $10 \%$ level, respectively. Robust standard errors are used in computing t-statistics. $\Delta$ law 1 is a dummy for waivable minimum service and non-agency. $\triangle$ law 2 is rescission of anti-rebate laws. $\Delta$ law 3 is all changes promoting unbundling combined. 
FIGURE 1: Regulatory Interventions in US Brokerage Industry

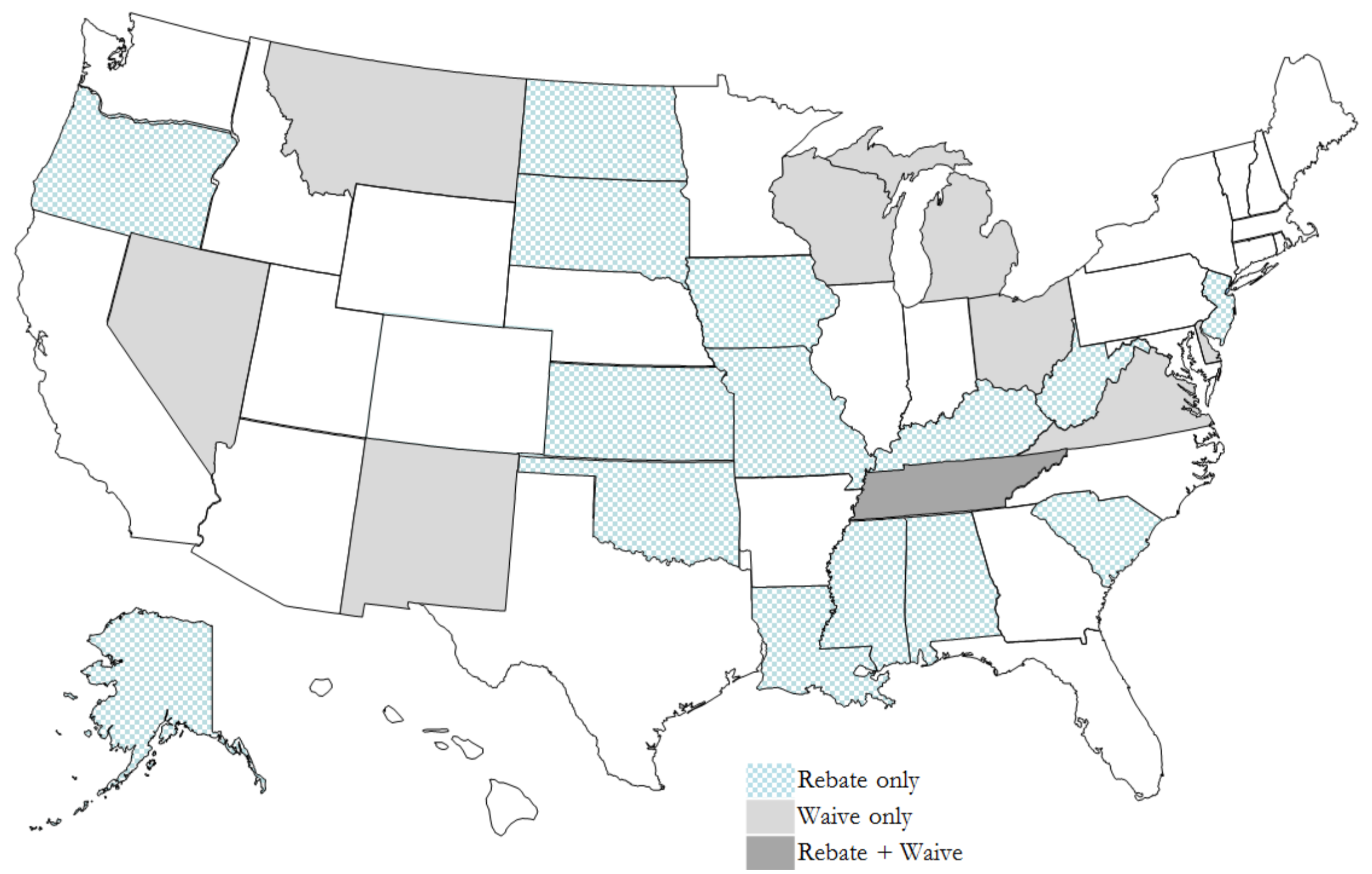

Note: 'Rebate' indicates presence of anti-rebate law. 'Waive' indicates presence of waivable minimum service law. 
FIGURE 2: Response of Brokers to Waivable Minimum Service Laws

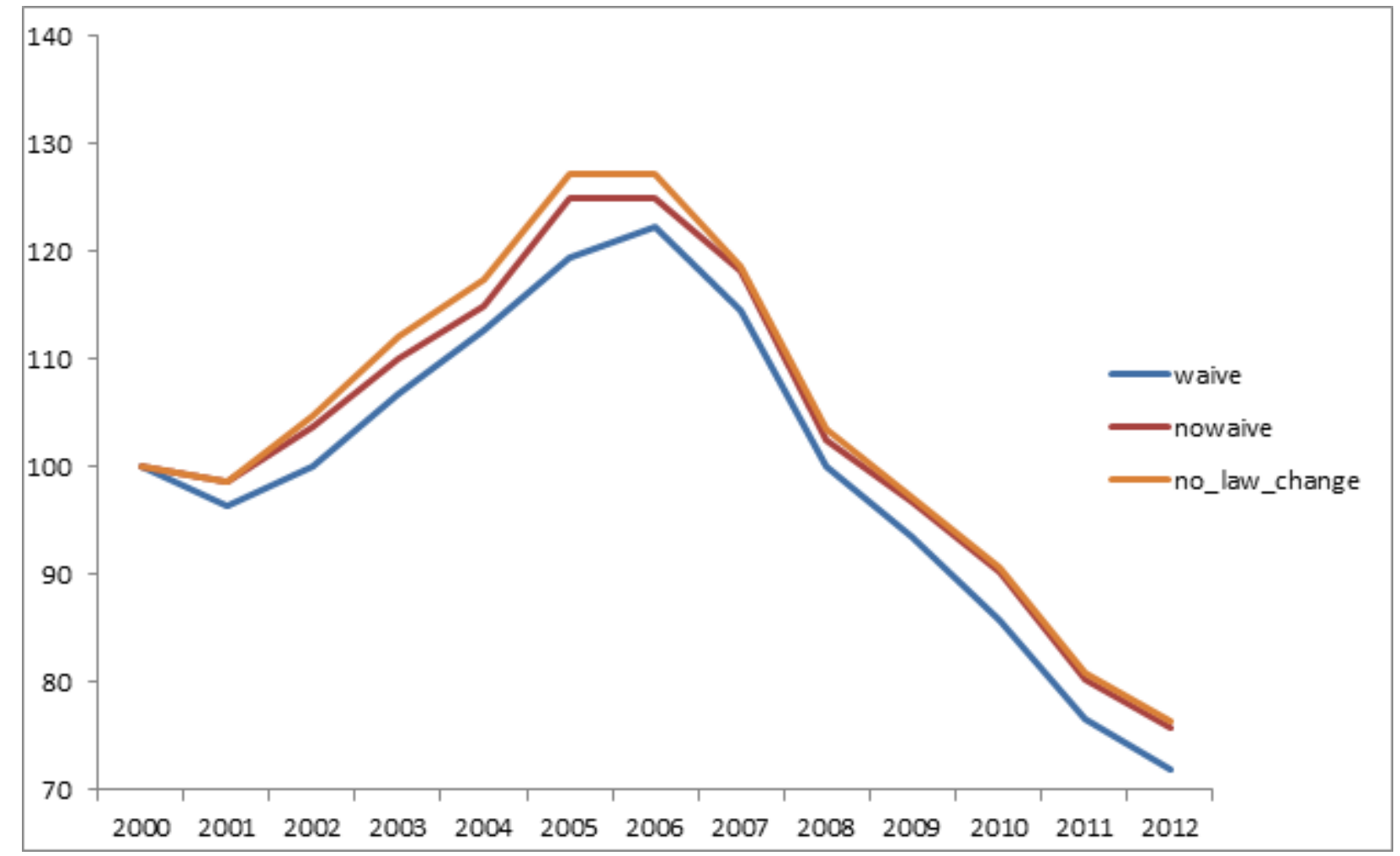

Note: Index of average NAR brokers in states that changed to allow waivable minimum services during 2000-2012 vs. states that did not allow this and states with no law change of any kind. 
FIGURE 3: Dynamic Response of Brokers to Rescission of Anti-Rebate Laws
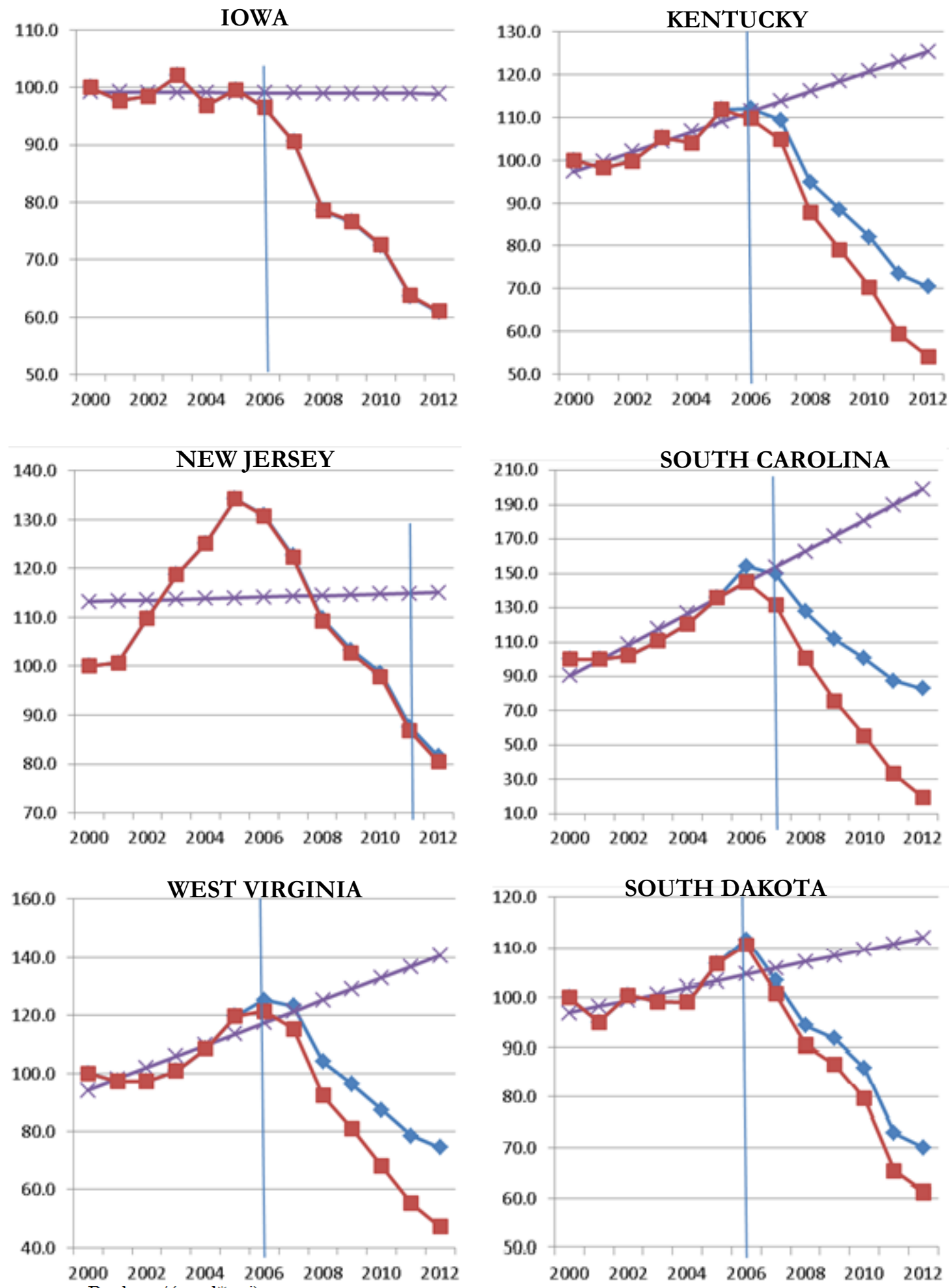

- Brokers/(popl*pci)

* pre-existing trend

$\rightarrow$-Brokers/(popl*pci) less pre-existing trend

*Vertical line at specific years shows law rescission in each state. 